\title{
Insights from a novel, user-driven science transfer program for resource management
}

\author{
J. L. M. Hinderer ${ }^{1}$ - Z. Blevins ${ }^{2}$. S. J. Cooke ${ }^{3}$ E. Dunlop ${ }^{4} \cdot$ K. F. Robinson ${ }^{5}$ - D. L. Stang ${ }^{6} \cdot$ T. J. Stewart ${ }^{7}$. J. T. Tyson ${ }^{1}$. \\ A. B. Welsh ${ }^{8} \cdot$ N. Young ${ }^{9} \cdot$ A. M. Muir ${ }^{1}$
}

Received: 19 June 2021 / Accepted: 27 August 2021 / Published online: 5 October 2021

(c) The Author(s) 2021

\begin{abstract}
Research results are often not easily accessible or readily digestible for decision-making by natural resource managers. This knowledge-action gap is due to various factors including the time lag between new knowledge generation and its transfer, lack of formal management structures, and institutional inertia to its uptake. Herein, we reflect on the Great Lakes Fishery Commission's Science Transfer Program and its evolution from 'Mode 1' (i.e., scientists conduct research autonomously) toward 'Mode 2' (i.e., co-production of knowledge with practitioners) knowledge production to understand and overcome the knowledge-action gap. Six success factors and strategies and tactics used to achieve those factors were critical to the shift from Mode 1 to Mode 2: (1) dedicate funding and staff support; (2) obtain top-down commitment from organizational leadership; (3) break down silos; (4) build relationships through formal and informal interactions; (5) emphasize co-production in program and project implementation; and (6) obtain buy-in among relevant actors. By way of three project case studies, we highlight knowledge transfer approaches, products, and lessons learned. We anticipate this contribution will benefit those working on knowledge mobilization, particularly in boundary-spanning organizations, and those involved in resource program management, administration, and design; it is also intended for resource managers seeking to have their science and information needs met more effectively.
\end{abstract}

Keywords Knowledge exchange $\cdot$ Knowledge mobilization $\cdot$ Knowledge-action gap $\cdot$ Boundary organization $\cdot$ Mode 2 knowledge production $\cdot$ Fishery management $\cdot$ Great Lakes

Submitted to: Socio-Ecological Practice Research (https://www. springer.com/journal/42532).

\section{A. M. Muir}

amuir@glfc.org

1 Great Lakes Fishery Commission, Suite 100, 2000

Commonwealth Blvd., Ann Arbor, MI 48105, USA

2 University of Michigan, Dana Building, 440 Church Street, Ann Arbor, MI 48109, USA

3 Department of Biology and Institute of Environmental and Interdisciplinary Science, Canadian Centre for Evidence-Based Conservation, Carleton University, 1125 Colonel Dr, Ottawa, ON K1S 5B6, Canada

4 Aquatic Research and Monitoring Section, Ontario Ministry of Northern Development, Mines, Natural Resources and Forestry, 2140 East Bank Drive, Peterborough, ON K9L 0G2, Canada
5 Quantitative Fisheries Center, Department of Fisheries and Wildlife, Michigan State University, East Lansing, MI 48824, USA

6 Division of Fish and Wildlife, New York State Department of Environmental Conservation, 625 Broadway, Albany, NY, USA

712 Ellice St, Kingston, ON K7K1M2, Canada

8 Division of Forestry and Natural Resources, West Virginia University, P.O. Box 6125, Morgantown, WV 26506, USA

9 School of Sociological and Anthropological Studies, University of Ottawa, 120 University Private, Ottawa, ON K1N 6N5, Canada 


\section{Closing the knowledge-action gap}

Natural resource management involves constant decisionmaking about complex social-ecological systems on multiple timescales (Mitchell 2018). Ideally, modern natural resource management is "science-based," insofar as scientific data, evidence, and knowledge are important inputs to these decisions (Ehrlich and Daily 1993) alongside other factors such as stakeholder and rightsholder interests, cultural priorities, economic considerations, and political priorities (Garcia and Cochrane 2005; Ludwig et al. 1993; Young 2015). However, it is increasingly clear that significant gaps exist between the data, evidence, and knowledge that are generated by researchers and those that are actually used by natural resource managers to make decisions (Arlettaz et al. 2010; Cvitanovic et al. 2015; Fabian et al. 2019; Newcomb et al. 2021). This so-called knowledge-action gap is due in part to the time lag between the generation of new knowledge (heretofore a shorthand term for data, evidence, and knowledge) and its communication and transfer, lack of formal management structures (i.e., statute, administrative code, or policy), as well as institutional inertia to its uptake (reviewed in Cook et al. 2013; see Table 1 for glossary of terms used herein). The gap is also due to more complex social phenomena, such as different professional cultures and expectations of scientists, knowledge holders, and managers (Young et al. 2013, p.349), inclinations to prefer "tried and true" and "socially defensible" methods over new knowledge or knowledge generated via new methods (Nowotny et al. 2003), and the structure of social networks in work environments that encourage people to turn to homologous colleagues for advice rather than to reach outside of their institutions or familiar networks (Young et al. 2016a). The knowledge-action gap is also associated with a lack of recognition by scientists of the regulatory and policy realms that are available to managers to implement the knowledge, which is why co-production is highly effective. The knowledge-action gap can be envisioned as three separate but intertwined "spheres" within a knowledge-action system: (i) knowledge production and coproduction; (ii) knowledge mediation; and (iii) knowledgeaction-closing the knowledge-action gap requires efforts across all three spheres (Nguyen et al. 2017, p.792).

Closing gaps between knowledge production and use is important, given that new knowledge can be highly useful to managers, that environmental conditions can shift rapidly and have complex, often cascading, effects, and that social expectations in the digital age are that managers be highly responsive to new developments and information (Brownscombe et al. 2019; Young et al. 2018). Direct social and organizational connections are important means of closing gaps and encouraging "science transfer" across networks and professional cultures (e.g., Guston 2001; Kirchhoff et al. 2015). While science communication is generally defined as a diffused activity for engaging broader publics (Burns et al. 2003, p.190), we conceptualize science transfer as more targeted, aiming to move specific knowledge and management tools directly to individuals and organizations involved in decision-making. Direct connections are often facilitated by individuals (called "knowledge brokers") and groups (called "boundary organizations") that are familiar with the cultures of scientists and managers, and that often stand with a foot in each world (Cash et al. 2003; Gustafsson and Lidskog 2018; Guston 2001; Meyer 2010). It is important to acknowledge that such transfer of knowledge is bidirectional rather than merely knowledge generators sharing their knowledge and findings with so-called knowledge users (Fazey et al. 2013, p.30).

\subsection{A shift toward Mode 2 knowledge production reduces the gap}

Documenting real-world characteristics that lead to successful science transfer and knowledge exchange in natural resource management continues to be a pressing need (Arlettaz et al. 2010; Cvitanovic et al. 2015; Nguyen et al. 2017). Moreover, the best practices require further refinement and adoption by both scientific and resource management communities. Therefore, our objectives were (1) to critically reflect on the evolution of the Great Lakes Fishery Commission's Science Transfer Program from 'Mode 1' (i.e., scientists conduct research autonomously) toward 'Mode 2' (i.e., co-production of knowledge with practitioners) knowledge production (Nowotny et al. 2003, p.180) to understand and overcome the knowledge-action gap; and (2) determine success factors and strategies and tactics employed to achieve success critical to the shift from Mode 1 to Mode 2 knowledge production. According to the Mode 1 model, science is "completed" before it is transferred to users as a series of tools, technologies, or principles (Hessels and Van Lente 2008). Mode 2 science adopts the more iterative model of co-production that involves collaboration among knowledge generators and users throughout the research process of problem definition, design, analysis, and application. Mode 2 principles can also be applied to Mode 1 science, albeit in a more limited fashion that focuses on actions in Nguyen et al.'s (2017) knowledge mediation sphere. The value of putting science to work has been globally recognized and for the past few decades prioritized to enhance effective use of public funding (Bogenschneider and Corbett 2011; Glaser et al. 1983). For instance, national research councils, such as the U.S. National Science Foundation and the U.K. Research Excellence Framework, consider 'broader impacts' or 'contributions to society' in their review processes (Holbrook 2005, p.439). Despite considerable effort, many challenges continue to limit knowledge transfer keeping the knowledgeaction gap open. As such, we intend this article to benefit 


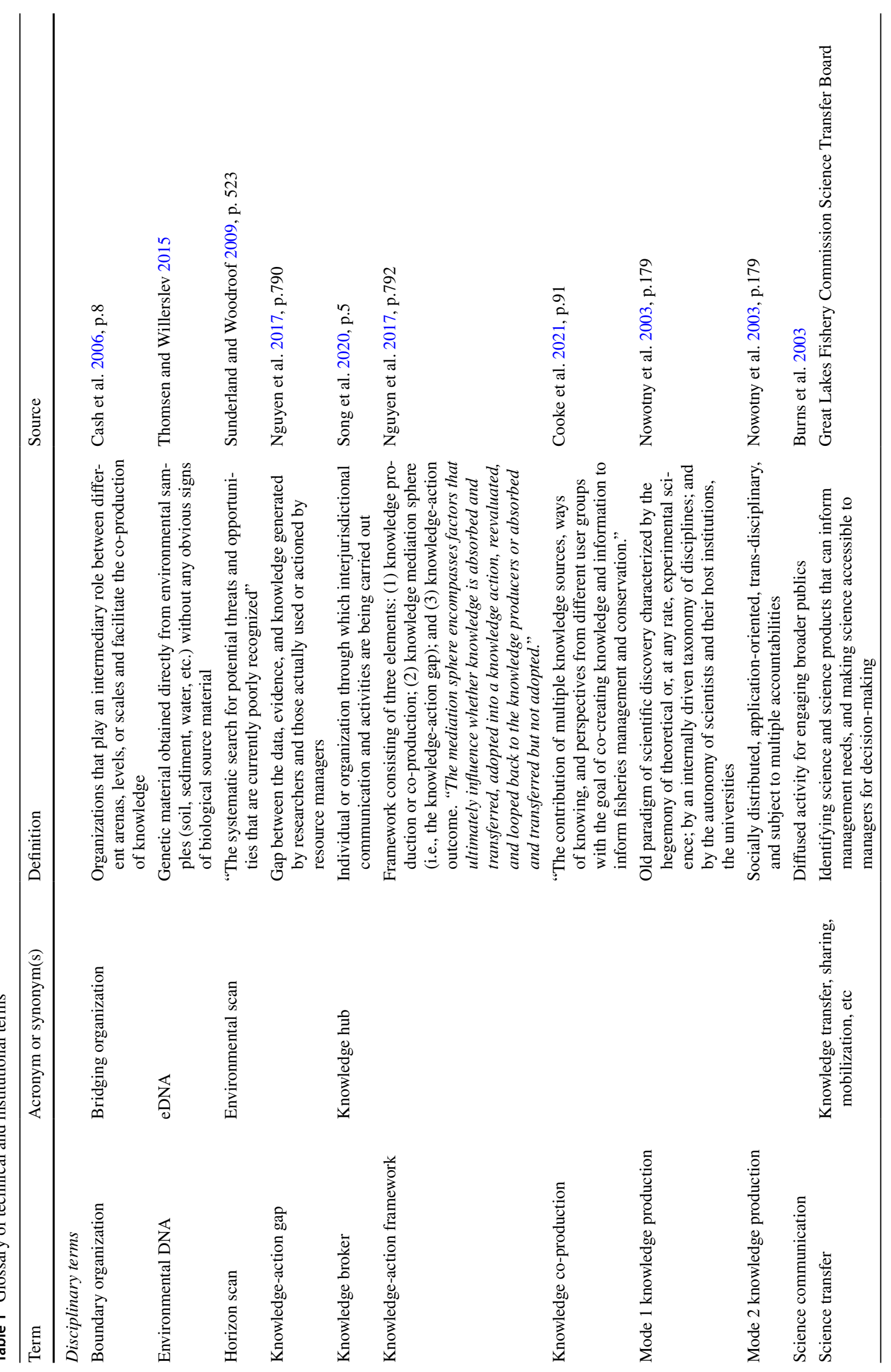




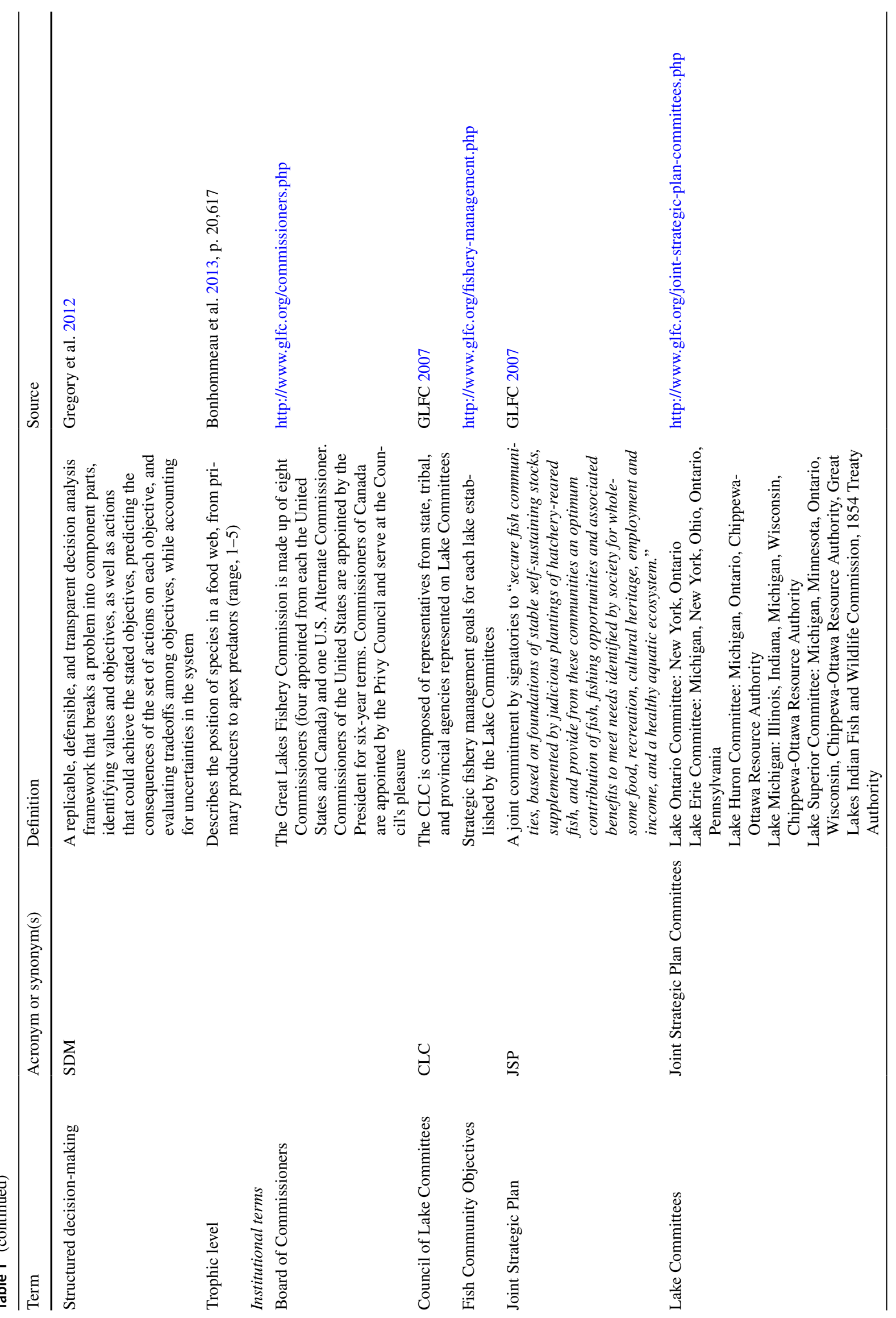


researchers and scholars working on knowledge mobilization, particularly in boundary-spanning organizations, and those involved in program management, administration, and design at government agencies, academic institutions, and conservation groups; it is also intended for higher-level resource managers and policymakers seeking to have their science and information needs met more effectively.

\section{Case study: A novel science transfer program provides a model for effective knowledge co-production and use}

Below we draw on lessons learned in the evolution of a novel science transfer program on the Laurentian Great Lakes of North America to determine key success factors in the transition from Mode 1 to Mode 2 knowledge generation.

\subsection{Laurentian Great Lakes fishery management}

The Laurentian Great Lakes (hereafter Great Lakes), covering more than $244,000 \mathrm{~km}^{2}$, support valuable subsistence, recreational, and commercial fisheries in both Canada and the United States of America (Fig. 1). The Great Lakes region is an economic powerhouse, supporting tourism, industry, and international trade along its shorelines and within its waterways (Krantzberg and De Boer 2008, p.102, Table 1). Each of the five Great Lakes has its own set of physical characteristics and fish assemblages, with both unique and shared resource management challenges. Across the basin, management of fisheries resources falls to the state and provincial governmental agencies and Indigenous communities (Gaden et al. 2008, 2012; GLFC 2021) for whom fish are important for culture, food, and the economy (see Fig. 1). Many commercially important fishes show large-scale movements across jurisdictional boundaries within lakes and sometimes even between lakes (Hayden et al. 2019; Matley et al. 2020; Riley et al. 2018). Sharing information and coordinating management among jurisdictions is therefore central to sustainable fishery management, especially given the wicked challenges facing managers in the Great Lakes, including invasive species, climate change, and nutrient loading that require joint strategies and actions across management entities and in some cases across lakes or the basin.

A coordinated basin-wide approach to Great Lakes fishery management was necessitated by collapse of major fisheries owing to commercial overharvest, habitat degradation, and invasive species (Gaden et al. 2013; Muir et al. 2012; Smith 1968). In response, the Great Lakes Fishery Commission was established by a 1954 Convention on Great Lakes Fisheries (hereafter convention) between the USA and Canada (U.S. Department of State 1956). The 


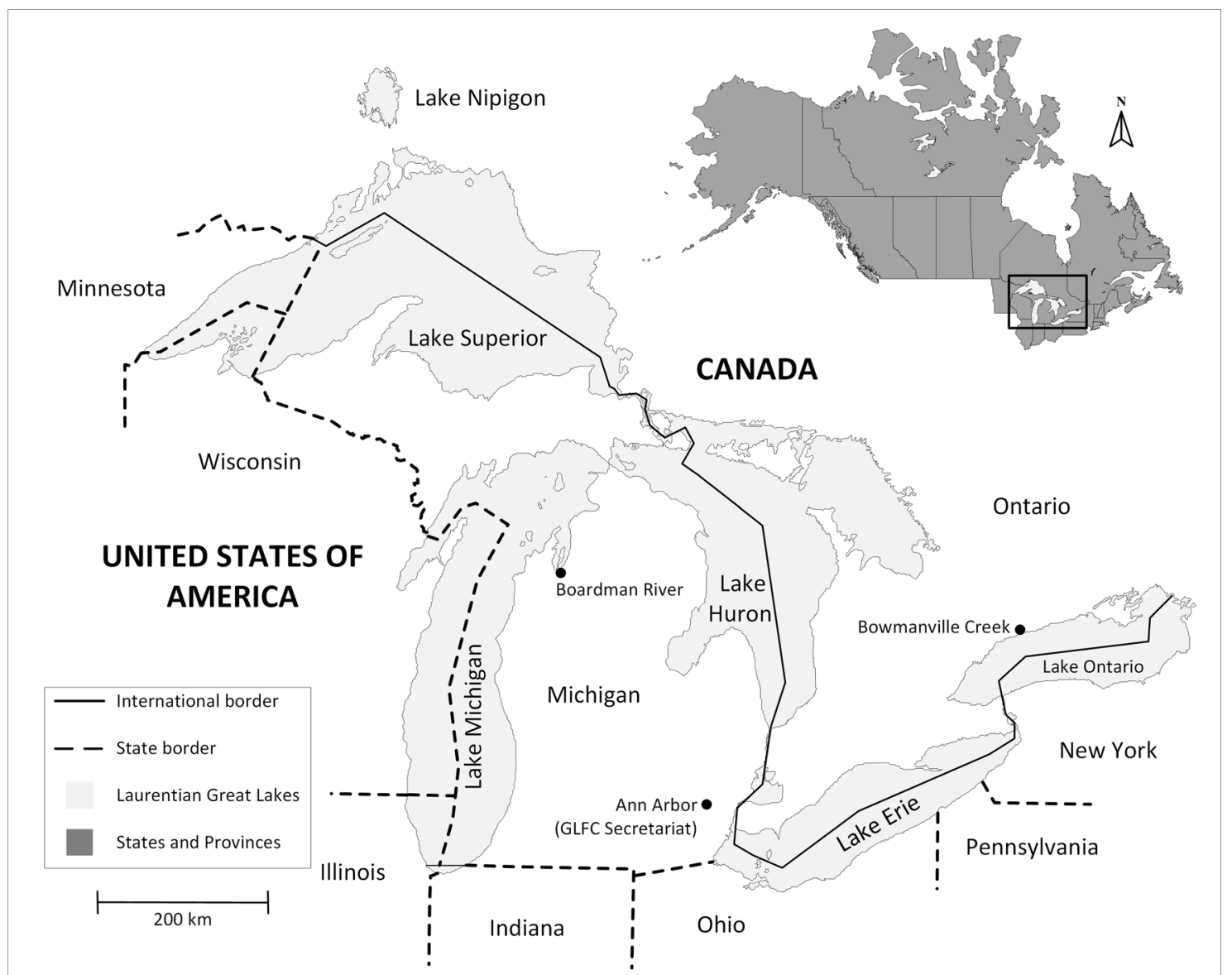

Fig. 1 Location of the North American Laurentian Great Lakes, Canada (north) and United States (south), the international boundary (solid black line), and the eight States and the Province of Ontario that have jurisdiction over fisheries (dashed lines). Additionally, may Indigenous Nations have jurisdiction throughout the Great Lakes

work of the commission is guided by a board of government-appointed Commissioners and supported by a secretariat staff, currently consisting of about 25 employees, based in Ann Arbor, Michigan, USA. The primary duties of the commission (per convention Article IV) are to control invasive sea lamprey Petromyzon marinus, coordinate fishery research, and inform and facilitate working arrangements for interjurisdictional management (U.S. Department of State 1956). The commission's Science Transfer Program is prosecuted as a partial fulfillment of three duties articulated in Article IV of the convention: (IV-b) to coordinate research made pursuant to such [research] programs and, if necessary, to undertake such research itself; (IV-c) to recommend appropriate measures to the Contracting Parties [the USA and Canada] on the basis of the findings of such research programs; and (IV-e) to publish or authorize the publication of scientific and other information obtained by the commission in the performance of its duties (U.S. Department of State 1956, basin. Locations mentioned within the text, including the Great Lakes Fishery Commission (GLFC) Secretariat headquarters, are also shown. Note that the scale is relevant to the Great Lakes as opposed to the inset

p.5). Importantly, article VI of the convention ensures that management authority for the Great Lakes remains clearly vested with the states, provinces, and Tribes. Article IV specifies the critical role of the commission in coordinating fishery management across jurisdictions, for example by implementing a Joint Strategic Plan for management of Great Lakes Fisheries (GLFC 2007), a non-binding agreement that establishes a common goal for Great Lakes fisheries and working arrangements (i.e., institutional and social networks) within which the parties work to achieve that goal. The Joint Strategic Plan is implemented by individual Lake Committees, which are the action arm of the Plan. Lake Committees are comprised of senior fisheries managers from each of the state, provincial, and US tribal management agencies that have jurisdiction on each particular lake. The Council of Lake Committees, comprised of all of the lake committee representatives, considers issues and problems of common concern affecting two or 
more of the individual lakes. The Sea Lamprey Control Board comprises officials from federal, state, provincial, and tribal fishery agencies along with invited non-governmental experts and assists the commission in developing and implementing strategies, policies, and programs related to control of invasive sea lamprey. The duties of the commission dictate its roles in all three areas of the knowledge-action framework (Nguyen et al. 2017).

\subsection{Re-imagining knowledge transfer in the Great Lakes basin}

In addition to supporting and guiding knowledge production and facilitating knowledge-action, the commission is uniquely positioned for science transfer within the knowledge mediation sphere (Nguyen et al. 2017) as a boundary organization (Cook et al. 2013; Cvitanovic et al. 2015; Selzer et al. 2020; Song et al. 2019). Although the convention provides authority for the Science Transfer Program, program effectiveness relies on the commission's long history of transboundary coordination and the strong interjurisdictional working relationships, both formal and informal, that comprise Great Lakes science and fishery management networks (Gaden et al. 2013; Leonard et al. 2011; Song et al. 2019). The Great Lakes are vast and governance is complex with more than 650 municipal to international jurisdictional units (McCrimmon Jr. et al. 2002, p. 250; Song et al. 2019). The commission functions as a "hub" or "broker" in these networks through which interagency communications occur (Song et al. 2019, p.11). Although knowledge exchange occurs organically through various functions of the commission, the Science Transfer Program seeks to mediate as much as possible of this knowledge exchange in a more formal way to ensure the information transferred is usable and actionable.

Early programs failed to achieve the commission's vision for science transfer (C. Krueger, pers. comm. 28 Aug 2020), largely because they were driven by scientists, lacked manager input, and produced technical products (i.e., Mode 1); evidence that these efforts had a tangible effect on fishery management decision-making was lacking (Table 2). In response, during 2013, commission staff and a former

Table 2 Evolution of the Great Lakes Fishery Commission (commission) Science Transfer Program from 'Mode 1' (i.e., scientists conduct research autonomously) toward 'Mode 2' (i.e., co-production of knowledge with practitioners) knowledge production

\begin{tabular}{|c|c|c|c|}
\hline Program & Coordination Activities Program & Science Transfer Program & New Science Transfer Program \\
\hline Years & 1995-2005 & 2006-2015 & 2015-present \\
\hline Program oversight & Science Director & Board of Technical Experts (BOTE) & Science Transfer Board \\
\hline Project solicitation & Directed & $\begin{array}{l}\text { External, competitive, request for } \\
\text { proposal }\end{array}$ & $\begin{array}{l}\text { Management issue-driven with Sci- } \\
\text { ence Transfer Board coordination }\end{array}$ \\
\hline Knowledge production mode & Mode 1 & Mode 1 & Mode 2 \\
\hline Objectives & Not documented & $\begin{array}{l}\text { 1) transfer knowledge to fishery } \\
\text { managers }\end{array}$ & $\begin{array}{l}\text { 1) identify science and science } \\
\text { products that can inform manage- } \\
\text { ment needs; } \\
\text { 2) make science accessible to man- } \\
\text { agers for decision-making to meet } \\
\text { these needs }\end{array}$ \\
\hline Types of projects and products & $\begin{array}{l}\text { Database development } \\
\text { Model development } \\
\text { Peer-reviewed publications } \\
\text { Science communications } \\
\text { Technical workshops }\end{array}$ & $\begin{array}{l}\text { Database development } \\
\text { Model development } \\
\text { Peer-reviewed publications } \\
\text { Science communications } \\
\text { Technical workshops } \\
\text { Web-based tools }\end{array}$ & $\begin{array}{l}\text { Knowledge exchange or training } \\
\text { workshops } \\
\text { Slide decks } \\
\text { Infographics } \\
\text { Decision trees } \\
\text { Fact sheets } \\
\text { Web-based data synthesis and visu- } \\
\text { alization apps }\end{array}$ \\
\hline Limitations & $\begin{array}{l}\text { Did not produce products that } \\
\text { were salient and timely for } \\
\text { managers } \\
\text { Lacked strategic direction } \\
\text { Lacked program documentation } \\
\text { Projects driven by scientists } \\
\text { largely for scientists } \\
\text { Projects and products highly } \\
\text { technical }\end{array}$ & $\begin{array}{l}\text { Did not produce products that were } \\
\text { salient and timely for managers } \\
\text { BOTE lacked science transfer } \\
\text { expertise } \\
\text { Limited management input } \\
\text { One-way communication to end- } \\
\text { users } \\
\text { Projects driven by scientists } \\
\text { Projects and products highly techni- } \\
\text { cal }\end{array}$ & $\begin{array}{l}\text { New, so more data needed to deter- } \\
\text { mine program efficacy } \\
\text { Not completely shifted to Mode } 2 \\
\text { Time and resources }\end{array}$ \\
\hline
\end{tabular}

The Board of Technical Experts is comprised of academic and agency scientists and fishery managers and advises on the commission's external fishery research funding program 
fishery manager conducted a strategic programmatic review of historical program documentation, previously funded projects, guidance provided to applicants, and program metrics such as number of proposals received, proportion of proposals funded, and the number of tangible products such as peer-reviewed publications and reports. Staff then undertook a SWOT (Strengths, Weaknesses, Opportunities, Threats) analysis and engaged in facilitated exercises to thoughtfully evaluate the Science Transfer Program and develop a renewed vision that would narrowly focus on an audience of high-level decision-makers at fishery management agencies, including those tasked with sea lamprey control, and would directly solicit relevant projects in addition to considering project ideas from external groups. Essentially, the new program represented a commitment toward Mode 2 of knowledge production (Nowotny et al. 2003), embracing two-way communication and co-production of usable, salient, and credible knowledge and further building trust among scientists and managers (Lemos et al. 2012, p.790).
Ultimately, a program was designed that created a 'learning space' to facilitate conversion of knowledge to more usable forms than peer-reviews articles (Stern et al. 2021, p.2) by placing scientists and managers at the same table to decide what issues to address and how to most effectively exchange knowledge. An advisory board consisting of representatives of fishery management and sea lamprey control agencies, along with natural and social scientists and science transfer experts, was formed to provide strategic direction and oversight and ensure that knowledge users are involved from early stages of project development. The Science Transfer Board worked with secretariat staff to develop a Terms of Reference (Supplement 1) and Code of Ethics to guide its activities. Secretariat staff and the Science Transfer Board collaborated to develop program goals and objectives and a process for achieving them. The two primary objectives of the Science Transfer Program are to (1) identify science and science products that can inform management needs, and (2) make science accessible to managers for

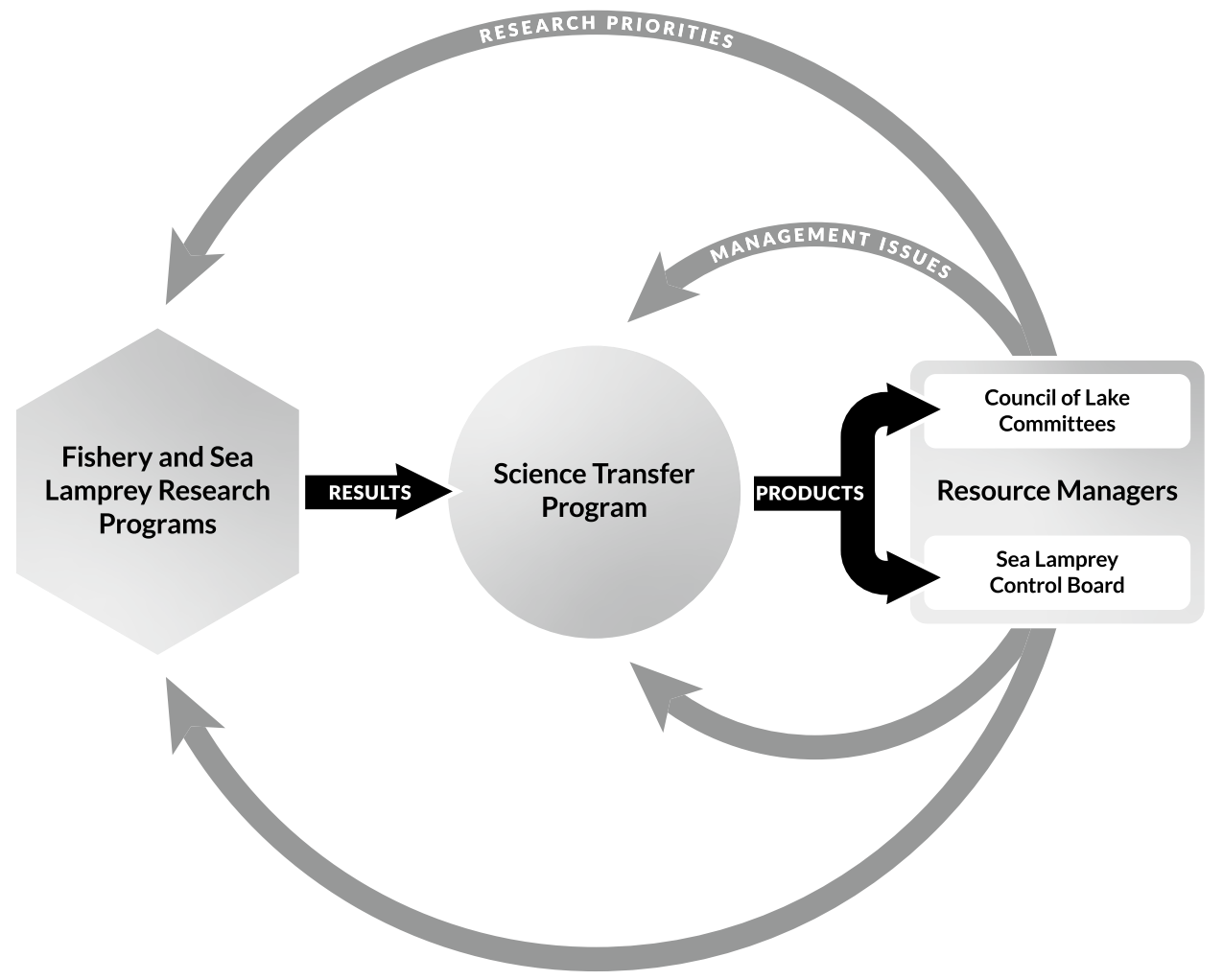

Fig. 2 Relationships among Great Lakes Fishery commission (commission) programs in identifying high-priority management issues and transferring scientific results in co-produced products to address those issues. The commission's Fishery (http://www.glfc.org/fishe ry-research.php) and Sea Lamprey (http://www.glfc.org/sea-lampr ey-research.php) Research Programs award funding to scientists in academia and government and are guided by research priorities established by advisory boards and resource managers, in particular the Council of Lake Committees (comprised of fishery managers from each of the Great Lakes; http://www.glfc.org/fishery-management. php) and the Sea Lamprey Control Board (comprised of sea lamprey control agents [Fisheries and Oceans Canada and the U.S. Fish and Wildlife Service], government and academic scientists, and fishery managers; http://www.glfc.org/taskforces/index.php?taskforce $=$ slcb). The Science Transfer Program works with the same groups of resource managers to understand their management priorities and facilitate transfer of research results through co-production of products that best meet those needs (http://www.glfc.org/science-transfer. php) 
decision-making to meet these needs. An engagement process was created to identify high-priority management issues through an ongoing "horizon scan" and regular brainstorming sessions with interjurisdictional resource management groups, including the Council of Lake Committees, the Sea Lamprey Control Board, and other technical support groups that are part of the commission's structure (Fig. 2). The Science Transfer Board annually reviews a list of potential project ideas, populated via these brainstorming sessions, and selects issues that are of high priority to fishery management and sea lamprey control and that can be informed by existing science that is at the appropriate stage to communicate to end-users. Figure 2 summarizes the role of the Science Transfer Program within the knowledge mediation sphere to identify high-priority management needs and "filter" science results from the commission's Fishery and Sea Lamprey Research Programs to meet those needs.

In addition to engaging in two-way knowledge exchange between producers and users at a programmatic level, the Science Transfer Program implements the Mode 2 strategy through project requirements, ensuring that managers are engaged in project design, development, and product development. Once topics have been selected for development into projects, staff and the Science Transfer Board identify project teams, consisting of both researchers and managers, to conduct the work. Projects build in regular opportunities for engagement with knowledge end-users, resulting in an iterative process of project implementation and product development (Fig. 3) that ensures end-user feedback is incorporated into products to effectively meet end-user needs. Project activities and final products often evolved from their original visions based on end-user interactions and feedback. In this way, the program and its outputs are designed for maximum adaptability and flexibility to ensure that needs of fishery managers and control agents are met.

\subsection{Key success factors for effective science transfer}

Below, we describe six success factors of the commission's Science Transfer Program we believe have been key to a shift from Mode 1 to Mode 2 of knowledge exchange (expanded upon in Table 3). Consideration of these factors and the key strategies and tactics employed to achieve the success factors was critical in implementing both the program and individual projects and helped close the knowledge-action gap

Fig. 3 Great Lakes Fishery Commission Science Transfer Program project implementation cycle

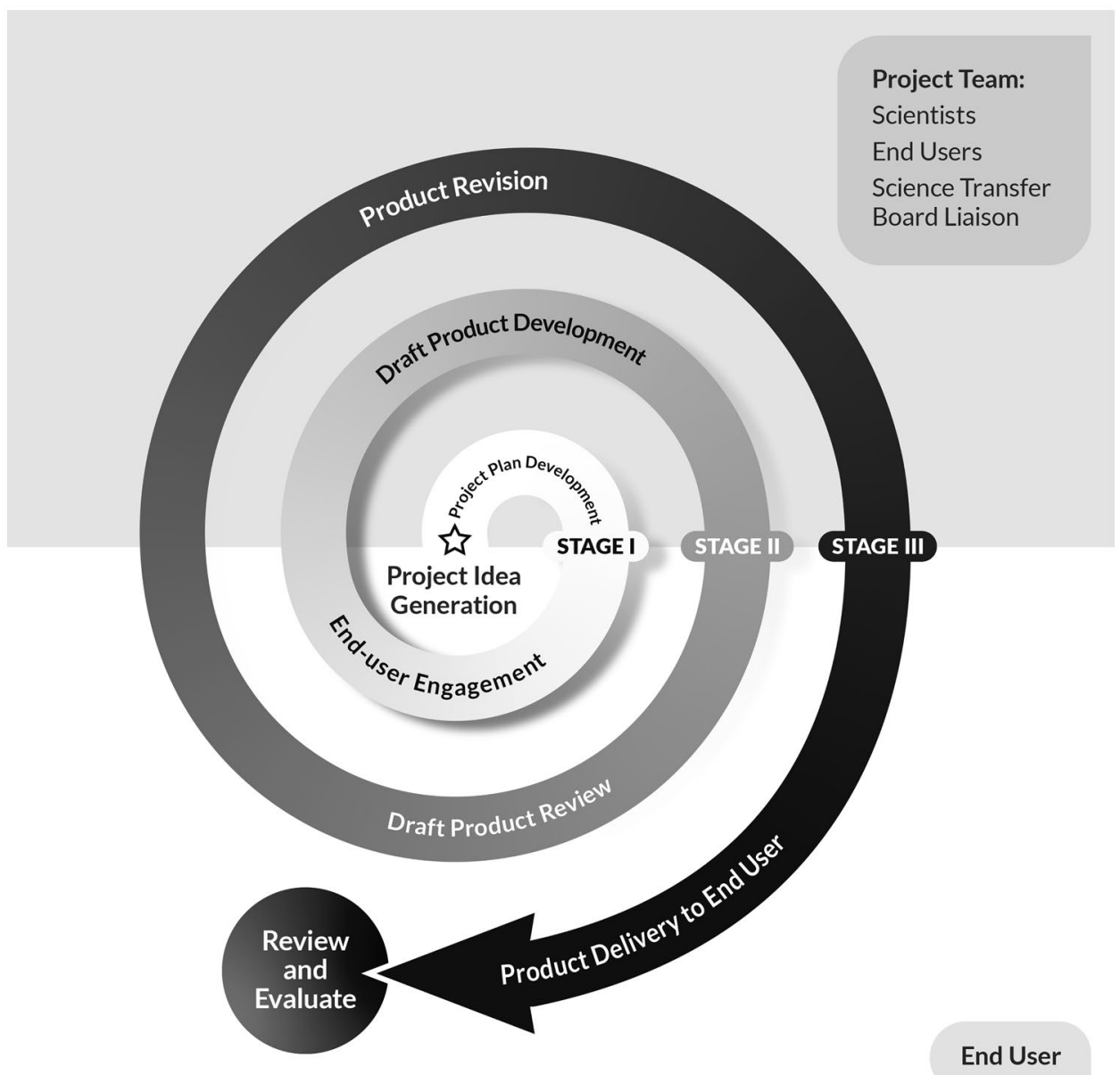




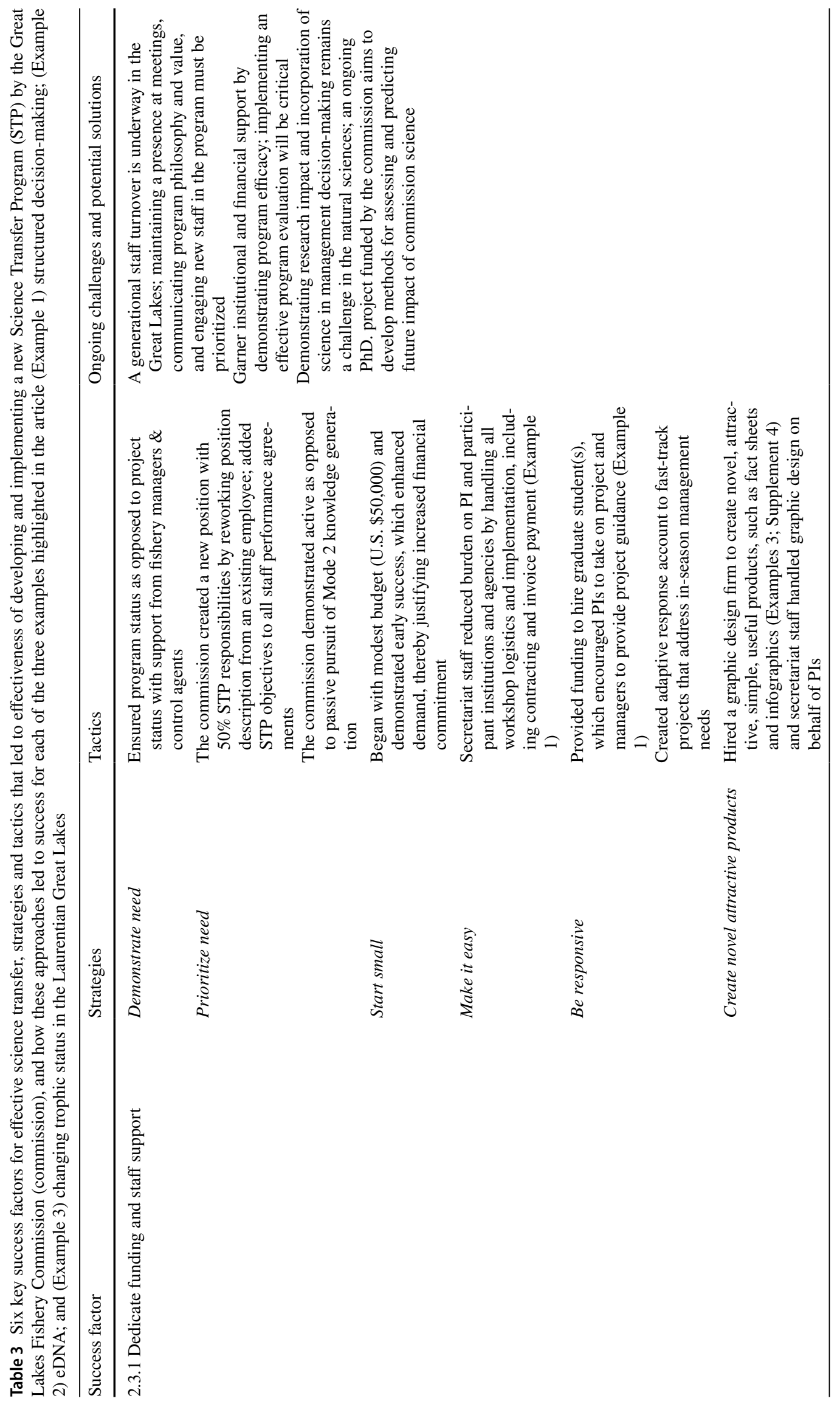




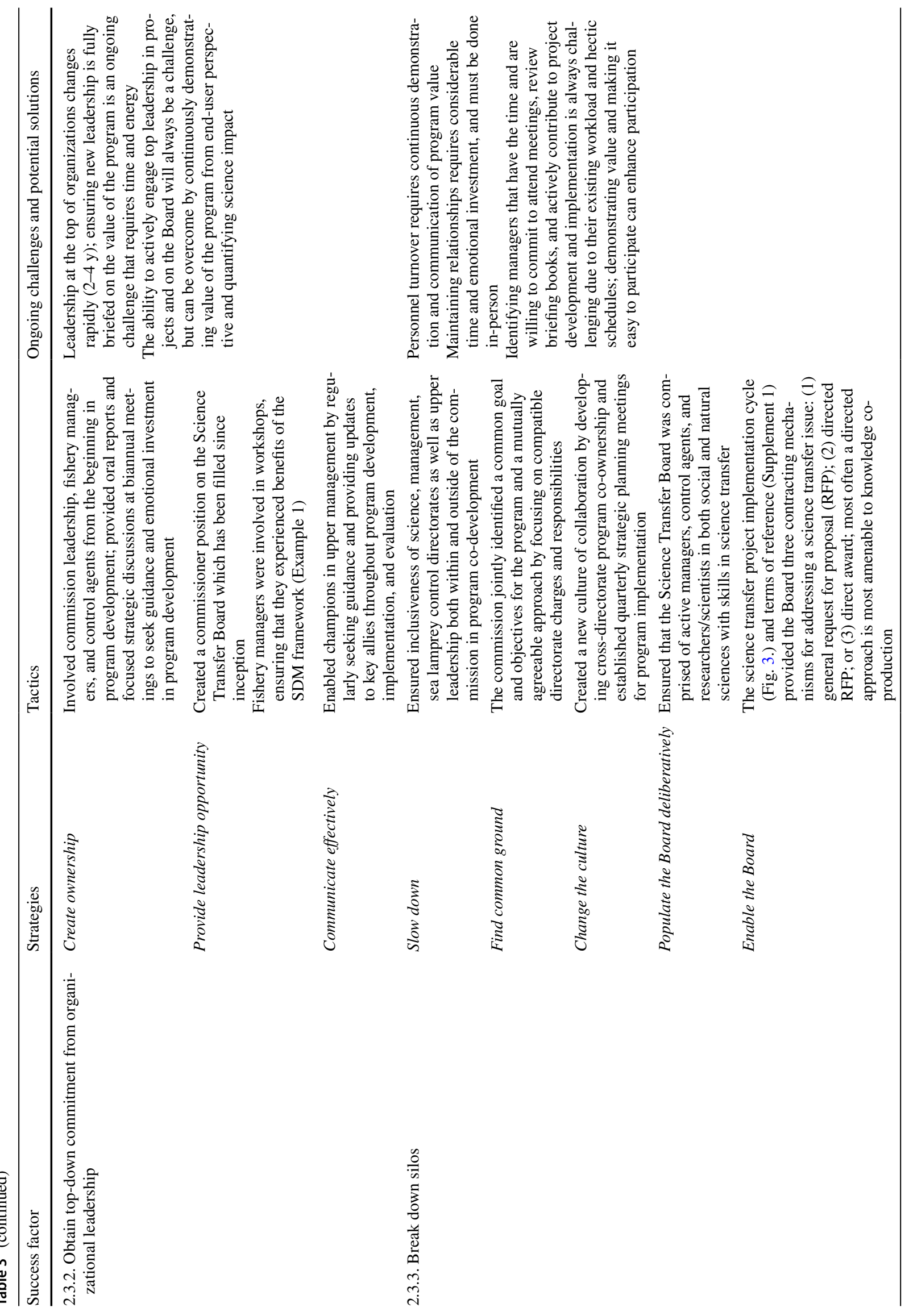




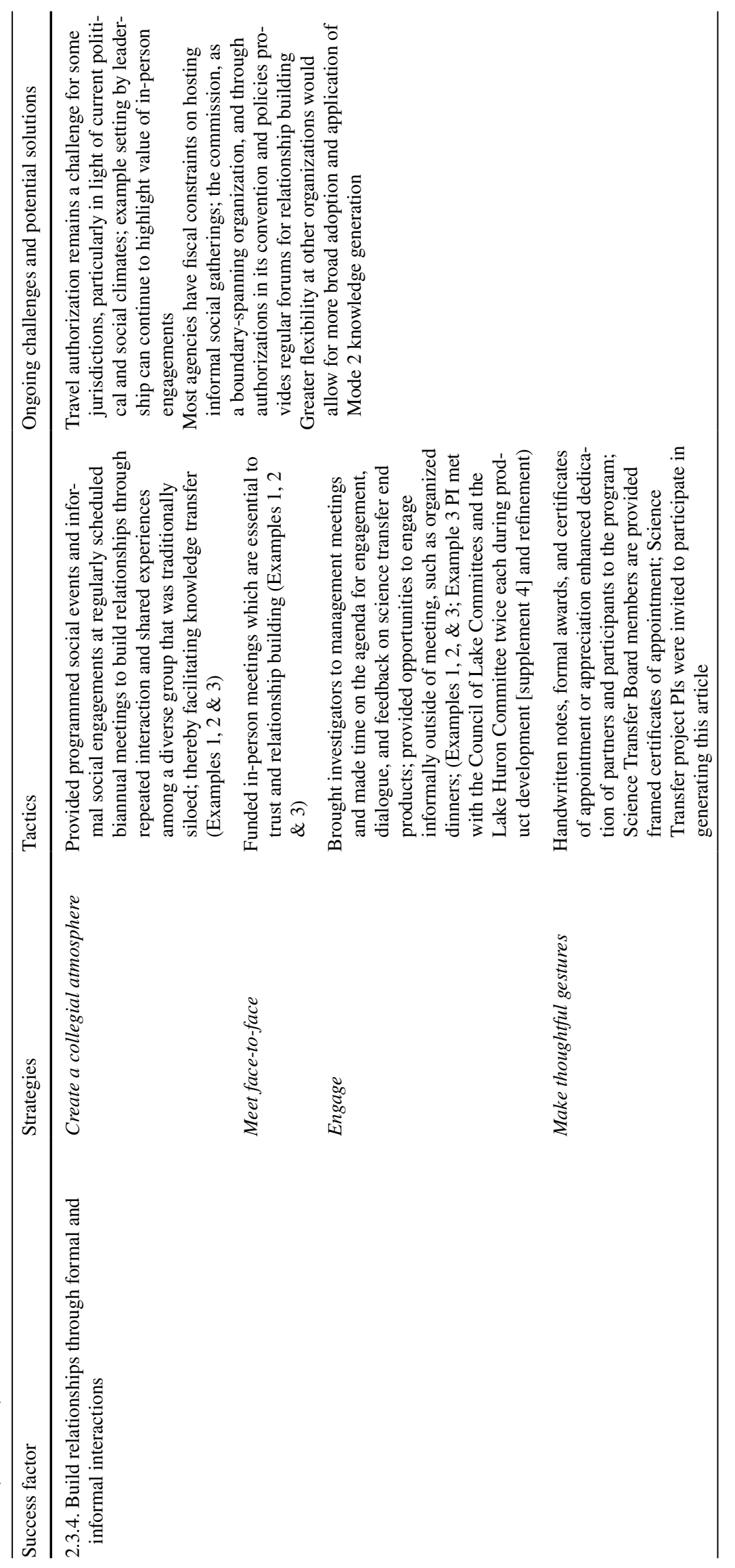




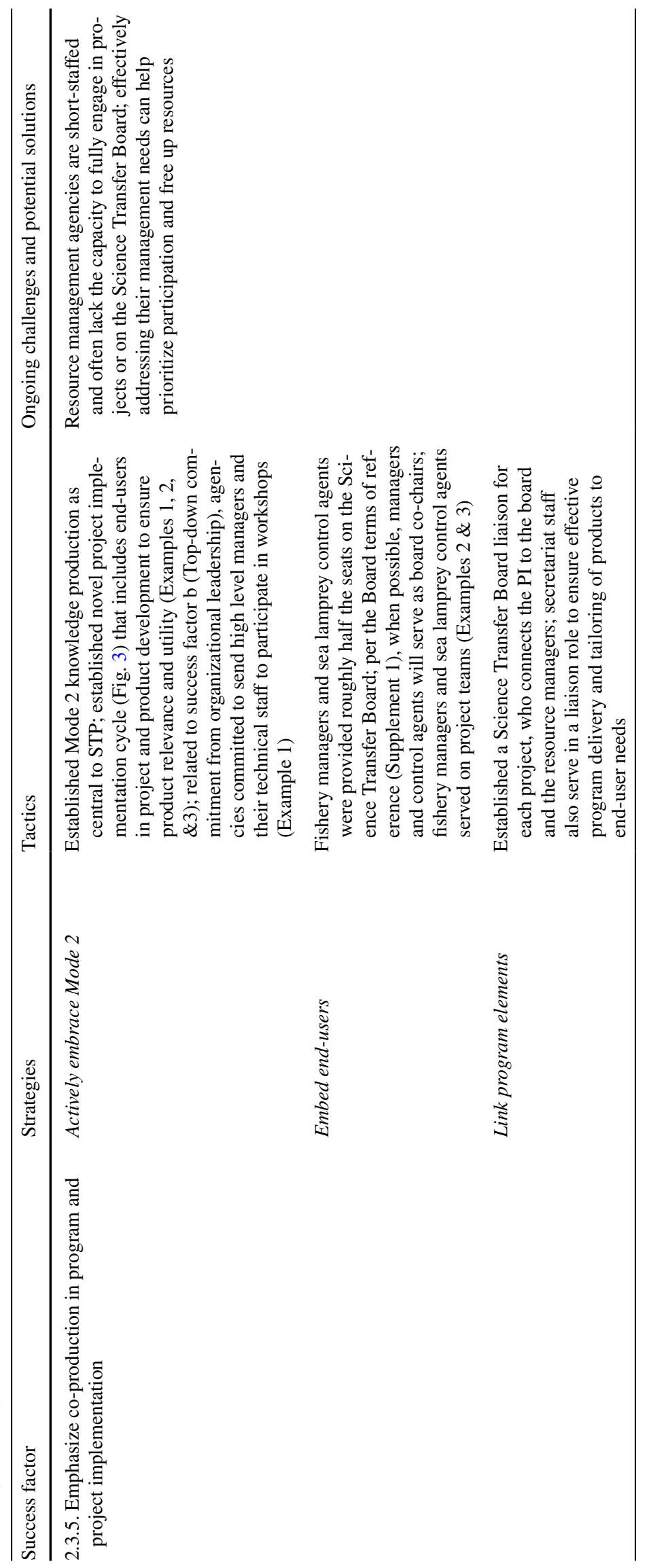




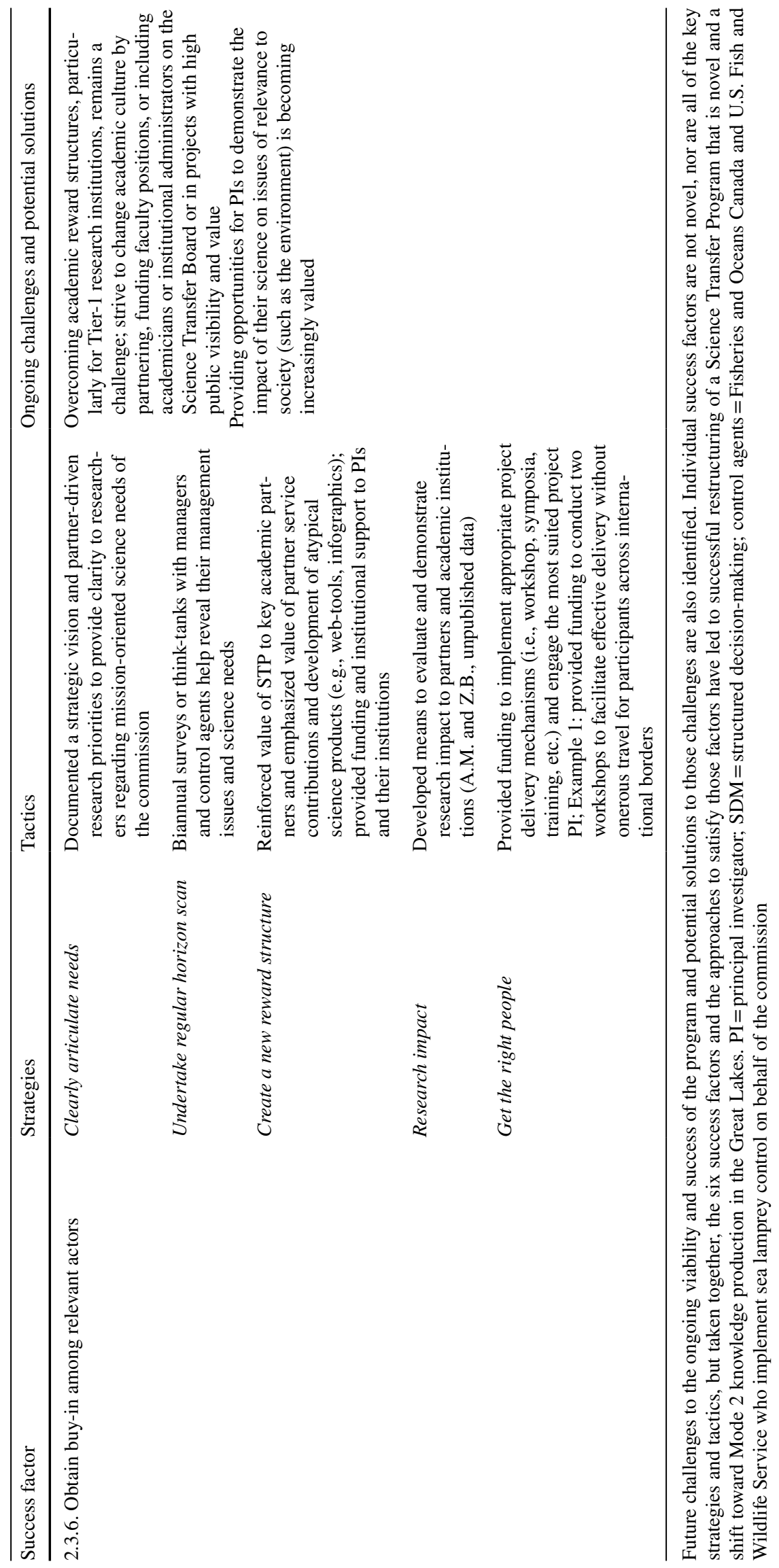


on various specific topics (see Examples 1-3) by creating an effective learning space (Stern et al. 2021). Most of the success factors identified pertain to the knowledge mediation sphere (Nguyen et al. 2017), as that is the arena in which the commission has the most influence. Organizations that seek to more effectively transfer knowledge, but primarily operate within the knowledge production/co-production or knowledge-action spheres, can still apply these principles to their work.

\subsubsection{Dedicate funding and staff support}

Adequate capacity in the form of dedicated human and financial resources is critical for successful knowledge exchange efforts (Nguyen et al. 2017; Reed et al. 2014, p. 343 and Table 1). Funds are required to bring Science Transfer Board members, principal investigators, and external experts together to formulate an annual program and collaborate on project development. In-person meetings allow for formal and informal discussion among scientists and managers, supporting creative knowledge mobilization projects targeted to manager needs, and also allow for regular feedback between the Science Transfer Board and project teams as projects progress. Perhaps most importantly, face-to-face, in-person interactions are the best way to develop trust and build relationships (see success factor 4; Cvitanovic et al. 2021, p.183). Adequate funding is also needed to deliver high-quality and effective knowledge transfer products. Creating attractive, simple, useful products such as fact sheets and infographics requires costly graphic design. Face-to-face interactions such as workshops are highly effective engagements to facilitate knowledge exchange, and require funding for participant travel, room rental fees, equipment and supplies, and nourishment. Providing funds for travel can be the difference in approval or denial of resource manager travel authorization for meeting participation. Dedicated staff time is also needed to develop and maintain program documentation, organize meetings, distribute meeting notes, follow up on action items, evaluate and refine program delivery, facilitate board activities and engagement with end-users, and disseminate science transfer products. The current Science Transfer Program is coordinated by a commission secretariat staff member who dedicates more than $50 \%$ of their time to the program, with at least a half-dozen other staff members across commission directorates contributing as needed to shepherd projects through the process (Fig. 3). The influence of secretariat staff in facilitating process, bridging groups, and influencing outcomes is critical to successful program implementation (Song et al. 2020) and extends through many of the subsequent success factors described below.

\subsubsection{Obtain top-down commitment from organizational leadership}

Commitment by the Great Lakes Fishery Commission's Board of Commissioners to effective science transfer has been critical to sustain needed funding and staff support for the Science Transfer Program. As part of this commitment, Commissioners were also willing to take an initial risk by fundamentally changing the commission's approach to science transfer; many organizations and institutions are not as nimble to pivot from conventional approaches. Annual review and Commissioner approval of funding allocations among the commission's program areas involves the assessment of return on investment of funds. Whereas results are more easily measured in the program areas of fishery management (e.g., jointly supported/implemented actions), sea lamprey control (e.g., sea lamprey population indices and fish wounding rates), and communications (e.g., website and social media metrics), the effectiveness or value of the contribution of knowledge generated by the research programs is not as easily evaluated, a challenge that plagues most natural resource programs (Penfield et al. 2014). Significant delay between knowledge development or transfer and its impact on policy and decision-making can occur (Nguyen et al. 2017; Reed et al. 2014), which necessitates a commitment to sufficient, long-term support for knowledge transfer. Commissioners have remained supportive of the research programs and continually confirm the need for applied science, its utility to decision-making, and the critical role of the Science Transfer Program in bridging the knowledge-action gap (e.g., unpublished minutes of the Great Lakes Fishery Commission Executive Meeting, 3-4 December 2015).

\subsubsection{Break down silos}

Institutional, organizational, and programmatic silos are barriers to developing an effective knowledge transfer program (Cvitanovic et al. 2015, p.27-28). In developing the current Science Transfer Program, identifying common goals and objectives fostered intra-organizational collaboration among the commission's science, fishery management, and sea lamprey control directorates. This collaboration resulted in a Science Transfer Board comprised of roughly equal numbers of fishery managers or sea lamprey control agents and scientists. Further, breaking down silos at the institutional level was critical to creation of and broad adoption of the project development and implementation cycle (Fig. 3) and for guiding individual projects through the cycle. For instance, the iterative process of bringing project plans and in-cycle updates to the managers for input would not have been possible without cross-directorate collaboration, agenda development, and commitment to continuous improvement of 
programmatic procedures. Removal of barriers helps ensure an effective participatory process that can promote relevant product development tailored specifically to manager needs and adoption and use of science products.

\subsubsection{Build relationships through formal and informal interactions}

Related to the problem of transcending silos, effective science transfer relies on strong, trusting social relationships across professional roles and cultures (Gaden et al. 2009, p.954). The "relational dimension" (i.e., the relationship and ties between knowledge-actors) of the knowledgeaction framework in natural resources (Nguyen et al. 2017) is critically important because knowledge is more readily transferred and accepted within relationships of mutual understanding, respect, and trust (Cvitanovic et al. 2021; Lemos et al. 2012; Young et al. 2016b). Social relationships are therefore key to successful knowledge exchange (Reed 2014; Song 2019). Meaningful social relationships are typically slow to form; they develop over time through repeated contacts across a variety of settings (Jack 2005; Matthews et al. 2009). Professional or workplace relationships have unique characteristics as well in that they often combine people with different roles and backgrounds and are therefore often more diverse than personal friendship networks. Workplace social relationships also tend to be more taskoriented, having both a formal side organized around work projects and instrumental goals and an informal side, which emerges through repeated interaction and shared experiences (Pillemer and Rothbard 2018, p.652). Activities and structure of the Science Transfer Board have been designed to nurture both the formal and informal side of relationships. By fostering collaboration between knowledge generators and users, the Science Transfer Board creates a formal arena for task-based knowledge exchange. However, the regularity of Science Transfer Board meetings and events also fosters informal interactions and shared experiences, putting people into repeated contact outside of work sessions. The dynamic between formal and informal interaction creates a virtuous circle, fostering the development of mutual trust and understanding (Mulvaney et al. 2015, p. 122). Trust is increasingly recognized as a fundamental concept in bridging the knowledge-action gap (Cvitanovic et al. 2021).

\subsubsection{Emphasize co-production in program and project implementation}

As discussed above, the Science Transfer Program embodies co-production of products at the program and project levels, which has increased relevance, usability, and transfer of knowledge to target users. The co-production approach implemented specifically refers to the inclusion, contribution, and iterative interaction of multiple knowledge sources and capacities from different stakeholders and rightsholders spanning the knowledge-action gap to cocreate knowledge (Lemos and Morehouse 2005; Meadow et al. 2015; Visbeck 2008; Wall et al. 2017; Wamsler 2017; Ziervogel et al. 2016) which is increasingly common in the fisheries realm (Cooke et al. 2021). True co-production and the leap to Mode 2 knowledge production was made possible by first breaking down programmatic silos (success factor 2.3.3). As evidenced by the project highlights in Examples $1-3$, implementing more deliberate forms of collaboration and co-production throughout multiple stages of the research and science transfer processes has improved communication on urgent research needs, benefitted study designs through end-user and researcher capacities and knowledge sources, and enhanced the tailoring and dissemination of knowledge so that it is more digestible and accessible for target audiences. A commitment to higher degrees of iterative interaction and co-production at multiple stages of the research process has been linked to increased accuracy, credibility, salience, and timeliness of research knowledge leading to higher levels of knowledge transfer and use (Arnott et al. 2020; Beier et al. 2017; Bremer and Meisch 2017; Cash et al. 2003, 2006; Dilling and Lemos 2011; Fujitani et al. 2017; Meadow et al. 2015; Michaels 2009; Reed 2008; Vogel et al. 2016).

\subsubsection{Obtain buy-in among relevant actors}

The commission is a mission-oriented organization with clear organizational focus laid out in the convention (U.S. Department of State 1956). Academics and resource agency staff, collectively embrace for the core mission to deliver science to support sea lamprey control and to contribute to healthy sustainable fish communities (GLFC 2021). The commission's research programs fund research specific to that mission and a primary evaluation criterion for proposals involves assessment of the extent to which the proposed science is relevant to commission priorities, and partner priorities. Those priorities are revisited and refined annually by managers and practitioners and shared with the scientific community so they are aware of science needs (Fig. 2). This level of transparency provides clarity to researchers on how to craft proposals with a greater likelihood of funding. However, feasibility and proposed approach — scientific qualityare given equal weight with relevance. Therefore, the commission has created a culture both within its various advisory boards and committees and among the broader fisheries science community that values high quality, mission-oriented research as the foundation for better management. This is most apparent in the willingness of researchers funded by the commission to engage directly with fishery managers and practitioners in the co-production of knowledge. Such 
interactions (e.g., at Council of Lake Committees meetings) create opportunities for scientists to share their knowledge and findings but also to learn what the management communities need to deliver their mission and these interactions foster knowledge co-production. Via the Science Transfer Program, there is opportunity to co-generate unique, tailored products that extend beyond peer-reviewed publications to include decision-support tools, software interfaces, databases, and management briefs. This creates multiple communication channels for new knowledge (see Decker and Krueger 1999, p.55-56) and enables the co-design of products tailored to the needs of end-users (Reed et al. 2014). This is a highly valued service to the commission community which breaks the traditional science value model where peer-reviewed publications are often considered the most important output (Moosa 2018). The traditional model is changing and the impact of science on issues of relevance to society (such as the environment) is becoming increasingly valued (Sinatra et al. 2016); the commission provides pathways for scientists to demonstrate such impact.

\section{Science transfer project examples}

Since inception in 2015, the Science Transfer Program has funded nine projects (Table 4) that range in objectives from empirical (e.g., gathering social science data to better understand barriers to information uptake by managers; Nguyen et al. 2021) to applied (e.g., co-producing applied products, such as fact sheets that synthesize scientific information in plain language). Here, we highlight three projects (Examples 1-3) that demonstrate how success factors (Table 3) contributed to the formulation of relevant and usable products that were readily implemented by resource managers. The examples were selected because they encompass the range of projects undertaken, types of project delivery mechanisms employed, approaches to engaging end-users, and types of products co-produced. Below, we explain these approaches, describe the final outputs or products developed, and discuss initial impressions from end-users and lessons learned from the perspective of project leaders. Final products from all projects are freely available for use and can be accessed on the Science Transfer Toolkit web page (http://www.glfc. org/science-transfer-toolkit.php). While the examples highlighted below are regional in nature and focus on local management issues, the scope of the examples is not pertinent to their purpose herein, which is to draw attention to the types of products, variety of project delivery mechanisms, and the role of success factors in successful knowledge exchange through Mode 2 co-production. Our intent is that lessons learned via the examples below will be broadly applicable to global management issues.

\subsection{Example 1}

An introduction to structured decision-making for fisheries managers.

\subsubsection{Management issue the project aimed to address}

Contentious tradeoffs exist between the costs and benefits of anthropogenic barrier removal in streams. Anthropogenic barriers (e.g., dams and road-stream crossings) often prevent native fishes from accessing critical habitat, but these same barriers provide benefit by blocking invasive species, such as sea lamprey, from colonizing or accessing upstream habitat-the so-called connectivity conundrum (McLaughlin et al. 2013; Zielinski et al. 2020) that must be accounted for in all decisions for barrier removal. However, predicting the ecological consequences of barrier removals is rife with uncertainties, and stakeholder values extend well beyond concerns with fish passage (Lin and Robinson 2019; McLaughlin et al. 2013). Managers needed a values-based, rigorous, and transparent process for confronting difficult barrier removal decisions in the face of varied and often conflicting stakeholder views.

\subsubsection{Project objectives and approach}

The science transfer objectives of the project were to:

(1) Present structured decision-making (SDM) as a framework to account for the many concerns and uncertainties surrounding barrier removal decisions; and

(2) Transfer the state of knowledge relevant to predicting fish production above barriers.

Two, 2-day "mock" (lacking decision-making authority) SDM workshops were held, one in the United States and one in Canada, using a regionally relevant dam removal project (i.e., Boardman River, MI and Bowmanville Creek, ON) as a case study. Attendees represented state and provincial fish and wildlife agencies, universities, Tribes and First Nations, and Canadian and U.S. federal agencies and included biologists and managers. Participants were introduced to the steps of SDM (problem definition, objectives setting, creating alternatives, predicting consequences, and making tradeoffs among objectives; Hammond et al. 1999) by working through the case studies (Jensen and Jones 2018; Lin et al. 2019). During the consequences step, four experts gave presentations about observations from barrier removals in Maine, predictions of sea lamprey production via modeling (Jensen and Jones 2018) and proxy species, and a decision support tool (Fishwerks; https://greatlakesconnectivity.org/) to prioritize barrier removals. The workshops concluded 


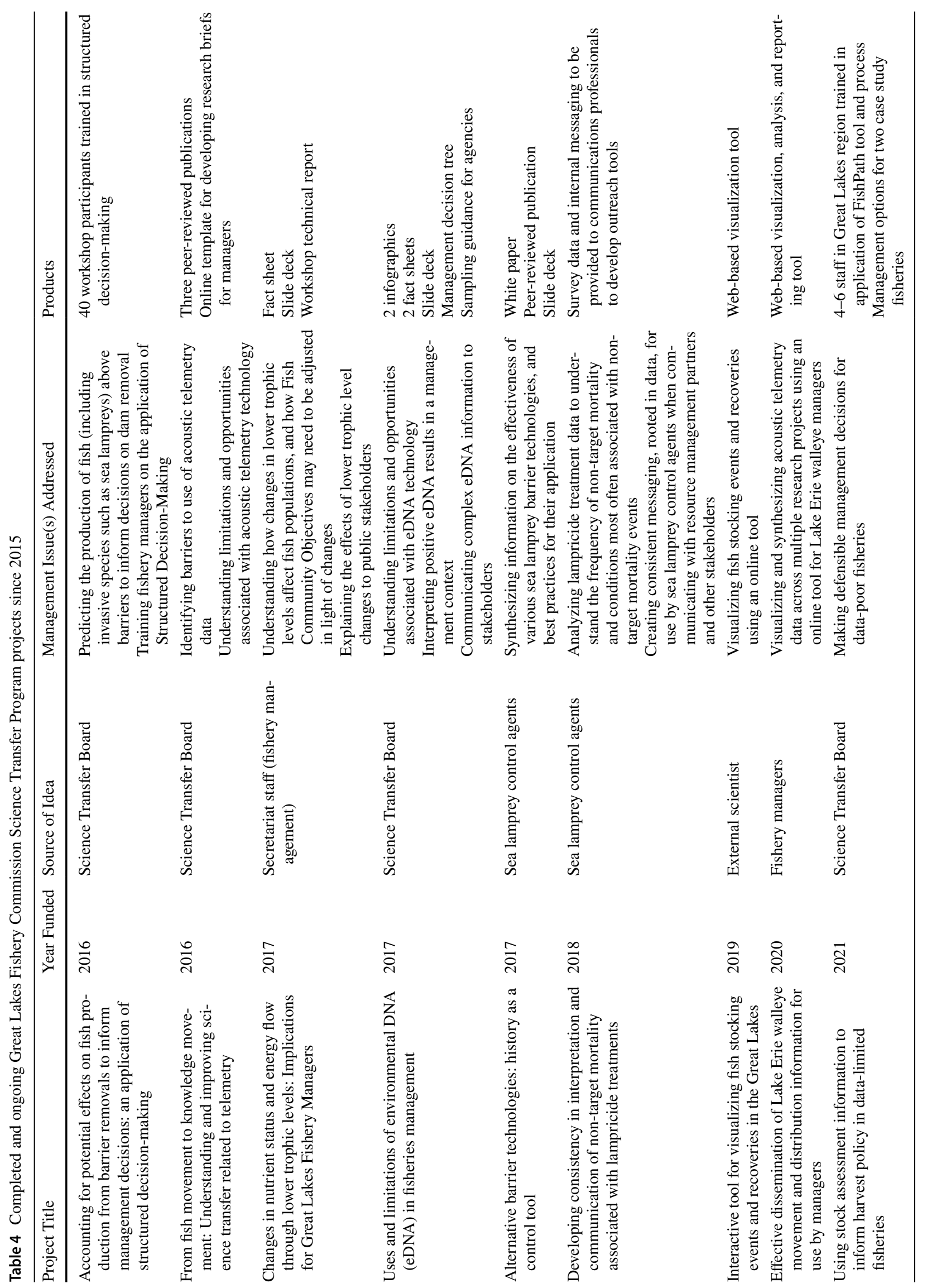


with discussions about making tradeoffs among management objectives and more generally about the use of SDM in barrier removal and other management decision-making.

\subsubsection{Final products and outputs}

Forty workshop participants were trained in SDM. Each participant received a copy of the book "Smart Choices: A Practical Guide to Making Better Decisions" (Hammond et al. 1999) and other workshop materials including presentations on the state of the science around barrier removals.

\subsubsection{Use and impact}

In a survey of workshop participants two years later, 69\% of respondents felt that lessons learned from the workshops have had either a "lot" or a "moderate" amount of influence on problem-solving in their professional lives. Although opportunities to implement SDM in full were scarce, many suggested that the ideals of SDM have allowed them to more fully consider values and objectives related to decision problems, as well as to broaden the scope of consideration for management decisions. The workshop format was subsequently used with biologists and managers in Ohio in 2018, for a separate problem combining SDM and decision support tools for barrier removals (Lin et al. 2019), again with positive feedback from participants. In addition, participant feedback provided valuable information regarding knowledge gaps for barrier removal decisions. Specifically, predicting productivity of fishes other than sea lamprey upon barrier removal remains uncertain and has led to fruitful areas of ongoing research in the basin (e.g., Lin and Robinson 2019).

\subsubsection{Lessons learned}

Ultimately, the SDM project achieved the science transfer objectives. Key factors contributing to the project's success were dedicated staff, including a graduate student, to plan and implement the workshops (success factor 2.3.1) and a firm commitment by the management agencies to send staff to participate (success factor 2.3.2). Both managers and their technical support staff participated in the workshops, which likely helped with future co-production. Finally, the workshops used highly relevant barrier removal case studies to demonstrate utility of the tools thereby enhancing participant engagement.

\subsection{Example 2}

Uses and limitations of environmental DNA (eDNA) in fisheries management.

\subsubsection{Management issue the project aimed to address}

Environmental DNA (eDNA) is a promising technique for increasing the chance of detecting relatively rare organisms in aquatic environments where they are present without having to capture or observe live specimens. Environmental DNA as a surveillance method has achieved regional prominence due to its early application for detection of non-native carps (i.e., Mylopharyngodon, Hypophthalmichthys, Ctenopharyngodon spp.) in the Great Lakes. Although eDNA shows potential as a cost-effective alternative to traditional surveillance methods, more effective communication between geneticists and managers is needed concerning the current limitations of eDNA and the biological interpretation of eDNA results.

\subsubsection{Project objectives and approach}

The science transfer objectives of the project were to:

1. Initiate a dialogue between eDNA experts and fishery managers to share current knowledge about eDNA uses and limitations and identify primary information needs of managers;

2. Provide easily accessible information to fishery managers to address the most significant information needs: a) biological interpretation of positive eDNA results, b) uses and limitations of eDNA, c) eDNA sampling guidance, and d) strategies for effectively communicating results to policy makers and the public.

A panel of eDNA experts convened with the Council of Lake Committees to identify informational needs among fishery managers regarding eDNA uses and limitations. During the meeting, participants were asked about the information they needed to effectively understand and communicate eDNA methods, results, and uncertainties to make betterinformed decisions, where communication of eDNA results seemed to break down, and how to better understand and implement actions in light of uncertainties associated with eDNA results. Based on this information, a set of project deliverables was developed to address the identified informational needs.

\subsubsection{Final products and outputs}

Deliverables were provided in a variety of accessible formats. A management support tree facilitated decisionmaking concerning the interpretation of positive eDNA results (Supplement 2). Two infographics were developed, one describing factors that influence eDNA presence in the environment (Supplement 3) and the other highlighting eDNA collection and analysis methods. Fact sheets for 
two different audiences (agency personnel and the public) provided background information on eDNA sampling, uses and limitations, and guidance on interpretation of results. A PowerPoint slide presentation with substantial notes and references was provided for manager use as a communication tool. Finally, a document summarizing key considerations for eDNA sampling was developed.

\subsubsection{Use and impact}

Importantly, products of the eDNA project were not designed for the public, but rather were developed specifically in consultation with and for fishery managers to empower them to more effectively interpret results, make informed decisions, and have the knowledge and confidence to effectively communicate those decisions to policy makers, stakeholders, rightsholders, and the broader public using a variety of formats. As evidence of the value of this project, follow-up discussions between the Council of Lake Committees and the Science Transfer Board have led to pursuit of an additional project to develop information tools and data standards to improve the reporting, reliability, and interpretation of eDNA information for management applications. Project leaders and staff plan to conduct a follow-up survey of managers two years after project completion to evaluate the degree to which products are being used and to understand additional needs. Preliminary website metrics indicate that products from this eDNA project are the most-downloaded Science Transfer Program products, with the PowerPoint presentation and infographics being accessed most frequently.

\subsubsection{Lessons learned}

The biggest challenges faced during transfer of eDNA knowledge were generating concrete and objective recommendations in the face of uncertainty (i.e., false positives and negatives), and creating dynamic products that can be updated in a rapidly developing field. Key success factors that helped overcome these challenges included breaking down silos by thoroughly understanding manager needs (success factor 2.3.3), building relationships through formal and informal interactions with fishery managers (success factor 2.3.5), and co-producing project products with multiple check-ins with the Council of Lake Committees throughout product development (success factor 2.3.5). These factors facilitated continual and open communication among the project team and with eventual end-users. Including a fishery manager on the core project team provided important perspective during project and product development and helped build bridges to knowledge users. Ongoing discussions with managers were necessary regarding the type of recommendations they needed and the level of uncertainty they were willing to accept. Peer review of the deliverables by both scientists and managers further strengthened the products.

\subsection{Example 3}

Changes in nutrient status and energy flow through lower trophic levels: Implications for Great Lakes fishery management.

\subsubsection{Management issue the project aimed to address}

The Great Lakes ecosystem has undergone profound changes over the last several decades, with implications for economically valuable recreational and commercial fisheries. Fishery managers need to understand how nutrient status and the composition of lower trophic levels of Great Lakes food webs have changed and how these may affect fish communities as they contemplate changes in fishery management activities and revisit fish community objectives. Further, managers need simple tools to communicate how and why lower food-web changes are influencing decisions about stocking or harvest strategies-a challenging concept to articulate in lay terms.

\subsubsection{Project objectives and approach}

The science transfer objectives of the project were to:

1. Synthesize information on lower trophic level status indicators in the Great Lakes during the last 20 years.

2. Develop a conceptual approach (terminology, common understanding, guiding principles, context relating to fisheries management processes) to assist fishery managers in understanding and communicating lower trophic level changes and their relationship to fisheries.

A 2.5-day technical workshop was held with approximately 25 scientists and technical experts. Fishery management input was provided via a project steering committee and limited participation (two managers) at the workshop. Workshop participants presented and discussed changes and trends in selected lower trophic level indicators and relevant case histories and hypotheses relating lower trophic level changes to fish communities and fisheries. Key elements of a conceptual model were developed during breakout groups and subsequently refined by the project team. Initial aspects of the conceptual model were presented to fishery managers for their feedback. Based on the refined conceptual model, 
the Lake Huron Committee (LHC) agreed to assist in development of a mock-up fact sheet for Lake Huron, which was presented to the Council of Lake Committees for discussion. In a follow-up extension of the project, a final Lake Huron fact sheet was completed.

\subsubsection{Final products and outputs}

Workshop proceedings and the original conceptual model were reported in a completion report to the commission. Final products for Lake Huron included professionally designed infographics and figures explaining the conceptual model, a fact sheet (Supplement 4), and a PowerPoint slide deck.

\subsubsection{Use and impact}

The conceptual model and Lake Huron fact sheet provided fishery managers knowledge and tools to effectively understand and communicate recent complex changes in the Lake Huron ecosystem and potentially help inform future revision of Lake Huron Fish Community Objectives (DesJardine et al. 1995), though the products are too new as of this writing for any formal evaluation of their use. The conceptual framework will be applied to other Great Lakes, with two other Lake Committees formally requesting fact sheets. This demonstration of demand from other end-users suggests that the Lake Huron knowledge products are being perceived as credible and accounts suggest they are being used effectively ( $R$. Claramunt, Michigan Department of Natural Resources, pers. comm. 27 April 2021). The project identified productive areas for future research including a more comprehensive understanding of the influence of water transparency on fishery dynamics and fish community composition, comparative studies of Great Lakes food web structure, and refining and challenging the conceptual model and its scientific underpinnings.

\subsubsection{Lessons learned}

Building relationships (success factor 2.3.4), emphasizing co-production (success factor 2.3.5), and getting buy-in from the research community (success factor 2.3.6) were critical factors in this project enabling a vast amount of dense science to be distilled into a useful framework for fishery managers. Initial discussions with managers and project proponents to refine the approach and scope were important. Enthusiastic volunteer participation of Great Lakes agencies and academicians and their open discussions and creativity were critical to product development. The ad-hoc steering committee developed to manage this collaboration was necessary and effective and the iterative engagement with managers (via the Council of Lake Committees and Lake Huron Committee) was critical to adoption of the final products.
Although limiting engagement to the Council of Lake Committees was efficient, the project may have benefitted from broader engagement with others in the fishery management community, an approach that will be considered when developing fact sheets for other lakes.

\section{Reflections and recommendations}

Thoughtful self-reflection five years into implementation of a new Science Transfer Program designed to close the knowledge-action gap allowed us to identify six key success factors for effective knowledge transfer at the program and project levels. While none of the success factors we identified explicitly overlapped with those recently presented by Newcomb et al. (2021), several commonalities occur and their model of research-management collaboration (their Fig. 1) is remarkably similar to the relationships supporting the GLFC Science Transfer Program (shown herein as Fig. 2). One key difference between the Newcomb et al (2021) model and our model is that their governance structure was issue- or projectspecific, whereas, the Great Lakes Fishery Commission, via the Joint Strategic Plan (GLFC 2007), provides the governance structure for implementation of a basin-wide program. While all six success factors identified are critically important and build off one another, other organizations seeking to bridge the knowledge-action gap and co-produce usable science products should in particular focus on investing time and resources into building relationships through both formal and informal interactions between knowledge producers and users, allowing them to shift from Mode 1 toward 2 of knowledge production (Nowotny et al. 2003). Relationships form the foundation of other key success factors by breaking down silos, building trust, and enabling co-production of credible and salient scientific information products. Such efforts are increasingly serving as foundational to achieving meaningful success in environmental research and management (Cooke 2020). The role of the Great Lakes Fishery Commission as a boundary-spanning organization provides opportunities to convene management jurisdictions, for example through biannual meetings, such as Council of Lake Committees and the Sea Lamprey Control Board. Regularly scheduled, in-person meetings provide "reporting out" and "receiving input" mechanisms for the Science Transfer Board that facilitate co-production and potentially in the future co-application of products and co-management of Great Lakes resources.

This article represents a first "pulse check" of the commission's revised Science Transfer Program. Thus far, evaluation of individual projects suggests that the program is successfully developing more salient and usable information products than in the past to effectively address specific management needs. Additionally, the Science Transfer Board has developed and adopted a plan that outlines protocols and 
metrics for evaluating projects and their outcomes at broader and longer scales than are typically considered in natural science evaluations. Various methods, including interviews and surveys of knowledge producers and users and a $\mathrm{PhD}$ project to measure the impact of commission-funded research on policy and practice are ongoing. Collectively, evaluations should increase understanding of the current elements of science transfer that lead to effective knowledge exchange, and ways the program can be adapted for continuous improvement to effectively meet manager information needs.

Historically, Mode 1 of knowledge production was the norm due to factors such as incentive structures, institutional silos, and continued desire to preserve the autonomy of science (Backer 1991; Stokes 1997). However, a shift to Mode 2 of knowledge production is underway, and recommendations on how to transition from Mode 1 to Mode 2 are salient across a broad range of disciplines including education, medicine, engineering, and environmental sciences (Guthrie et al. 2013). We hope that using Mode 2 to create learning spaces and co-produce secondary science products will eventually lead to more co-produced initial research being proposed conducted, and integrated into management decision-making - a true shift to Mode 2 in the knowledge production sphere. We recognize that some of the strategies and tactics implemented by the Commission will not be relevant or feasible for science and management entities elsewhere; however, we remain optimistic that some of the creative approaches described herein will inspire actions to promote more effective knowledge transfer and a shift toward Mode 2 knowledge co-production with resource managers. If fishery managers and scientists jointly develop research questions, pose hypotheses, and plan and conduct projects to test these hypotheses, then knowledge will more effectively lead to action and intermediary knowledge brokers or boundary organizations will play a less critical role in the future. In other words, the ultimate measure of success of any science transfer program will be when it is no longer needed.

Supplementary Information The online version contains supplementary material available at https://doi.org/10.1007/s42532-021-00093-4.

Acknowledgements We thank U.S. Commissioner David Ulrich and his colleagues for the inspiration to take a deep dive into the efficacy of the Commission's Science Transfer Program, which ultimately led to its overhaul in 2015. Thanks to Dr. Charles C. Krueger for accepting that challenge and leading us through the review process and the initial stages of program revision. Dr. Marc Gaden (Great Lakes Fishery Commission) and Mr. Gary Isbell (retired Ohio Department of Natural Resources) were also essential to the program review and Dr. John Dettmers (Great Lakes Fishery Commission) to its evolution. Dr. Krueger also provided important historical and philosophical perspective for this manuscript. Thanks to past and current Science Transfer Board members for guiding us through the evolution of the program toward Mode 2 co-production of knowledge. We sincerely thank all those who contributed to historical Commission science transfer efforts-new insights in no way denigrate the excellent contributions of the past, but rather, highlight a continuous effort to better achieve our goals by committing to funding, breaking down barriers, relationship building, and shifting the academic reward model. Finally, we thank Great Lakes fishery managers and scientists, who have come together to co-produce unique products that move science rapidly into action for the benefit of society. Funding for the work described herein was provided by the Great Lakes Fishery Commission and included considerable in-kind contributions from co-author's institutions.

Author contributions All co-authors contributed fully to the preparation and review of the manuscript.

Funding Funding for the work described herein was provided by the Great Lakes Fishery Commission and includes considerable in-kind contributions from the co-author's institutions.

Availability of data and material All Commission Science Transfer Products are freely available here: http://www.glfc.org/science-trans fer-toolkit.php. Data are available upon request.

\section{Declarations}

Conflicts of interest We are not aware of any conflicts of interest or competing interest.

Consent for publication All co-authors agreed to submission of the manuscript for publication.

Open Access This article is licensed under a Creative Commons Attribution 4.0 International License, which permits use, sharing, adaptation, distribution and reproduction in any medium or format, as long as you give appropriate credit to the original author(s) and the source, provide a link to the Creative Commons licence, and indicate if changes were made. The images or other third party material in this article are included in the article's Creative Commons licence, unless indicated otherwise in a credit line to the material. If material is not included in the article's Creative Commons licence and your intended use is not permitted by statutory regulation or exceeds the permitted use, you will need to obtain permission directly from the copyright holder. To view a copy of this licence, visit http://creativecommons.org/licenses/by/4.0/.

\section{References}

Arlettaz R, Schaub M, Fournier J, Reichlin TS, Sierro A, Watson JE, Braunisch V (2010) From publications to public actions: when conservation biologists bridge the gap between research and implementation. Bioscience 60:835-842

Arnott JC, Neuenfeldt RJ, Lemos MC (2020) Co-producing science for sustainability: Can funding change knowledge use? Glob Environ Chang 60:1-12

Backer TE (1991) Knowledge utilization: the third wave. Knowledge 12:225-240

Beier P, Hansen LJ, Helbrecht L, Behar D (2017) A how-to guide for coproduction of actionable science. Conserv Lett 10:288-296

Bogenschneider K, Corbett TJ (2011) Evidence-based policymaking: insights from policy-minded reserachers and research-minded policymakers. Routledge, New York

Bonhommeau S, Dubroca L, Le Pape O, Barde J, Kaplan DM, Chassot E, Nieblas AE (2013) Eating up the world's food web and the human trophic level. Proc Natl Acad Sci U S A 110:20617-20620

Bremer S, Meisch S (2017) Co-production in climate change research: reviewing different perspectives WIREs Climate Change 8 
Brownscombe JW, Adams AJ, Young N, Griffin LP, Holder PE, Hunt J, Danylchuk AJ (2019) Bridging the knowledge-action gap: A case of research rapidly impacting recreational fisheries policy. Mar Policy 104:210-215

Burns TW, O'Connor DJ, Stocklmayer SM (2003) Science communication: a contemporary definition. Public Underst Sci 12:183-202

Cash DW, Clark WC, Alcock F, Dickson NM, Eckley N, Guston DH, Jäger J, Mitchell RB (2003) Knowledge systems for sustainable development. Proc Natl Acad Sci 100:8086

Cash DW, Adger WN, Berkes F, Garden P, Lebel L, Olsson P, Pritchard L, Young O (2006) Scale and cross-scale dynamics: Governance and information in a multilevel world. Ecol Soc 11

Cook CN, Possingham HP, Fuller RA (2013) Contribution of systematic reviews to management decisions. Conserv Biol Ser (camb) 27:902-915

Cooke SJ, Rytwinski T, Taylor JJ, Nyboer EA, Nguyen VM, Bennett JR, Smol JP (2020) On "success" in applied environmental research-What is it, how can it be achieved, and how does one know when it has been achieved? Environ Rev 28:357-372

Cooke SJ, Nguyen VM, Chapman JM, Reid AJ, Landsman SJ, Young N, Hinch SG, Schott S, Mandrak NE, Semeniuk CAD (2021) Knowledge co-production: A pathway to effective fisheries management, conservation, and governance. Fisheries 46:89-97

Cvitanovic C, Hobday AJ, van Kerkhoff L, Wilson SK, Dobbs K, Marshall NA (2015) Improving knowledge exchange among scientists and decision-makers to facilitate the adaptive governance of marine resources: A review of knowledge and research needs. Ocean Coast Manag 112:25-35

Cvitanovic C, Shellock RJ, Mackay M, van Putten EI, Karcher DB, Dickey-Collas M, Ballesteros M (2021) Strategies for building and managing 'trust' to enable knowledge exchange at the interface of environmental science and policy. Environ Sci Policy 123:179-189

Decker DJ, Krueger CC (1999) The process of fisheries management. In: Kohler CC, Hubert WA (eds) Inland fisheries management in North America, 2nd edn. American Fisheries Society, Bethesda, Maryland, pp 61-81

DesJardine RL, Gorenflo TK, Payne RN, Schrouder JD (1995) Fishcommunity objectives for Lake Huron Great Lakes Fishery Commission. Special Publication, Ann Arbor, Michigan, pp 95-101

Dilling L, Lemos MC (2011) Creating usable science: Opportunities and constraints for climate knowledge use and their implications for science policy. Glob Environ Chang 21:680-689

Ehrlich PR, Daily GC (1993) Science and the management of natural resources. Ecol Appl 3:558-560

Fabian Y, Bollmann K, Brang P, Heiri C, Olschewski R, Rigling A, Holderegger R (2019) How to close the science-practice gap in nature conservation? information sources used by practitioners. Biol Conserv 235:93-101

Fazey I, Evely AC, Reed MS, Stringer LC, Kruijsen J, White PCL, Newsham A, Jin L, Cortazzi M, Phillipson J, Blackstock K, Entwistle N, Sheate W, Armstrong F, Blackmore C, Fazey J, Ingram J, Greson J, Lowe P, Morton S, Trevitt C (2013) Knowledge exchange: a review and research agenda for environmental management. Environ Conserv 40:19-36

Fujitani M, McFall A, Randler C, Arlinghaus R (2017) Participatory adaptive management leads to environmental learning outcomes extending beyond the sphere of science. Sci Adv 3:e1602516

Gaden M, Krueger CC, Goddard CI, Barnhart G (2008) A joint strategic plan for management of great lakes fisheries: a cooperative regime in a multi-jurisdictional setting. Aquat Ecosyst Health Manag 11:50-60

Gaden M, Krueger CC, Goddard CI (2009) Managing across jurisdictional boundaries: fishery governance in the great lakes and Arctic-Yukon-Kuskokwim regions. Am Fish Soc Symp 70:941-960
Gaden M, Goddard C, Read J (2012) Multi-jurisdictional management of the shared Great Lakes fishery: transcending conflict and diffuse political authority. In: Taylor WW, Ferreri CP (eds) Great Lakes fishery policy and management: a binational perspective, 2nd edn. Michigan State University Press, East Lansing, Michigan, pp 305-337

Gaden M, Goddard CI, Read J (2013) A history of multi-jurisdictional management of the shared Great Lakes fishery: transcending conflict and diffuse political authority. In: Taylor WW, Lynch AJ, Leonard NJ (eds) Great Lakes Fisheries Policy and Management. Michigan State University Press, East Lansing, pp 305-337

Garcia S, Cochrane K (2005) Ecosystem approach to fisheries: a review of implementation guidelines. ICES J Mar Sci 62:311-318

Glaser EM, Albelson HH, Garrison KN (1983) Putting knowledge to use: facilitating the diffusion of knowledge and the implementation of planned change. Jossey-Bass, San Francisco

GLFC (2007) A joint strategic plan for management of Great Lakes fisheries (adopted in 1997 and supersedes 1981 original). Great Lakes Fishery Commission Miscellaneous Publication, Ann Arbor, Michigan

GLFC (2021) Strategic vision of the Great Lakes Fishery Commission 2021-2025. http://www.glfc.org/pubs/SpecialPubs/StrategicV ision2012.pdf.

Gregory RS, Failing L, Harstone M, Long G, McDaniels TL, Ohlson D (2012) Structured decision making: a practical guide to environmental management choices. Wiley-Blackwell, West Sussex, United Kingdom

Gustafsson KM, Lidskog R (2018) Boundary organizations and environmental governance: Performance, institutional design, and conceptual development. Clim Risk Manag 19:1-11

Guston DH (2001) Boundary organizations in environmental policy and science: an introduction. Sci Technol Human Values 26:399-408

Guthrie S, Wamae W, Diepeveen S, Wooding S, Grant J (2013) Measuring research: A guide to research evaluation frameworks and tools. Prepared for the association of American medical colleges. Rand Corporation, Europe

Hammond JS, Keeney RL, Raiffa H (1999) Smart choices: a practical guide to making better life decisions. Broadway Books, New York, NY

Hayden TA, Vandergoot CS, Fielder DG, Cooke SJ, Dettmers JM, Krueger CC (2019) Telemetry reveals limited exchange of walleye between lake Erie and lake Huron: movement of two populations through the Huron-Erie corridor. J Gt Lakes Res 45:1241-1250

Hessels LK, Van Lente H (2008) Re-thinking new knowledge production: A literature review and a research agenda. Res Policy 37:740-760

Holbrook JB (2005) Assessing the science-society relation: The case of the US National Science Foundation's second merit review criterion. Technol Soc 27:437-451

Jack SL (2005) The role, use and activation of strong and weak network ties: A qualitative analysis. J Manag Stud 42:1233-1259

Jensen AJ, Jones ML (2018) Forecasting the response of Great Lakes sea lamprey (Petromyzon marinus) to barrier removals. Can J Fish Aquat Sci 75:1415-1426

Kirchhoff CJ, Lemos MC, Kalafatis S (2015) Narrowing the gap between climate science and adaptation action: The role of boundary chains climate. Risk Manage 9:1-5

Krantzberg G, De Boer C (2008) A valuation of ecological services in the Laurentian Great Lakes basin with an emphasis on Canada. Am Water Works Assoc J 100:100-111

Lemos MC, Morehouse BJ (2005) The co-production of science and policy in integrated climate assessments. Glob Environ Chang 15:57-68

Lemos MC, Kirchhoff CJ, Ramprasad V (2012) Narrowing the climate information usability gap Nature. Clim Change 2:789-794

Leonard NJ, Taylor WW, Goddard CI, Frank KA, Krause AE, Schechter MG (2011) Information flow within the social network structure of a joint strategic plan for management of great lakes fisheries. N Am J Fish Manag 31:629-655 
Lin HY, Robinson KF (2019) How do migratory fish populations respond to barrier removal in spawning and nursery grounds? Theor Ecol 12(3):379-390

Lin HY, Robinson KF, Jones ML, Walter L (2019) Using structured decision making to overcome scale mismatch challenges in barrier removal for watershed restoration. Fisheries 44(11):545-550

Ludwig D, Hilborn R, Walters C (1993) Uncertainty, resource exploitation, and conservation: lessons from history. Ecol Appl 260:17-36

Matley JK, Faust MD, Raby GD, Zhao Y, Robinson J, MacDougall T, Hayden TA, Fisk AT, Vandergoot CS, Krueger CC (2020) Seasonal habitat-use differences among lake erie's walleye stocks. J Gt Lakes Res 46:609-621

Matthews R, Pendakur R, Young N (2009) Social capital, labour markets, and job-finding in urban and rural regions: comparing paths to employment in prosperous cities and stressed rural communities in Canada. The Sociol Rev 57:306-330

McCrimmon DA Jr (2002) Sustainable fisheries management in the great lakes: scientific and operational challenges. Lake Reservoir Manag 7:241-254

McLaughlin RL, Smyth ERB, Castro-Santos T, Jones ML, Koops MA, Pratt TC, Ve'lez-Espino L (2013) Unintended consequences and trade-offs of fish passage. Fish Fish 14:580-604

Meadow AM, Ferguson DB, Guido Z, Horangic A, Owen G, Wall T (2015) Moving toward the deliberate coproduction of climate science knowledge Weather. Climate, and Society 7:179-191

Meyer M (2010) The rise of the knowledge broker. Sci Commun 32:118-127

Michaels S (2009) Matching knowledge brokering strategies to environmental policy problems and settings. Environ Sci Policy 12:994-1011

Mitchell B (2018) Resource and environmental management. Oxford University Press, England

Moosa IA (2018) Publish or perish: Perceived benefits versus unintended consequences. Edward Elgar Publishing, UK

Muir AM, Krueger CC, Hansen MJ (2012) Re-establishing lake trout in the Laurentian Great Lakes: past, present, and future. In: Taylor WW, Lynch AJ, Leonard NJ (eds) Great Lakes fisheries policy and management: a binational perspective, 2 nd edn. Michigan State University Press, East Lansing, pp 533-588

Mulvaney KK, Lee S, Höök TO, Prokopy LS (2015) Casting a net to better understand fisheries management: An affiliation network analysis of the Great Lakes Fishery Commission. Mar Policy 57:120-131

Newcomb TJ, Simonin PW, Martinez FA, Chadderton WL, Bossenbroek JM, Cudmore B, Hoff MH, Keller RP, Ridenhour BD, Rothlisberger JD, Rutherford ES, Van Egeren S, Lodge DM (2021) A best practices case study for scientific collaboration between researchers and managers. Fisheries (bethesda) 46:131-138

Nguyen VM, Young N, Cooke SJ (2017) A roadmap for knowledge exchange and mobilization research in conservation and natural resource management. Conserv Biol 31:789-798

Nguyen VM, Delle Palme C, Pentz B, Vandergoot CS, Krueger CC, Young N, Cooke SJ (2021) Overcoming barriers to transfer of scientific knowledge: integrating biotelemetry into fisheries management in the Laurentian great lakes. Socio-Ecological Practice Research 3:17-36

Nowotny H, Scott P, Gibbons M (2003) Introduction: 'Mode 2' revisited: The new production of knowledge. Minerva 41:179-194

Penfield T, Baker MJ, Scoble R, Wykes MC (2014) Assessment, evaluations, and definitions of research impact: A review. Res Eval 23:21-32

Pillemer J, Rothbard NP (2018) Friends without benefits: Understanding the dark sides of workplace friendship. Acad Manag Rev 43:635-660

Reed MS (2008) Stakeholder participation for environmental management: A literature review. Biol Conserv 141:2417-2431

Reed MS, Stringer LC, Fazey I, Evely AC, Kruijsen JH (2014) Five principles for the practice of knowledge exchange in environmental management. J Environ Manag 146:337-345

Riley SC, Binder TR, Tucker TR, Krueger CC (2018) Evidence of repeated long-distance movements by lake charr Salvelinus namaycush in Lake Huron. Environ Biol Fishes 101:531-545
Selzer M, Jonas JL, Pebbles V, Kosek-Sills S, Allan JW (2020) Crossing boundaries between science and policy: two case studies illustrate the importance of boundary organizations in the great lakes basin. J Gt Lakes Res 46:933-946

Sinatra R, Wang D, Deville P, Song C, Barabási AL (2016) Quantifying the evolution of individual scientific impact. Science 354:496

Smith SH (1968) Species succession and fishery exploitation in the great lakes. J Fish Res Board Can 25:667-693

Song AM, Temby O, Kim D, Saavedra Cisneros A, Hickey GM (2019) Measuring, mapping and quantifying the effects of trust and informal communication on transboundary collaboration in the Great Lakes fisheries policy network. Glob Environ Change 54:6-18

Song AM, Temby O, Kim D, Hickey GM (2020) Assessing the influence of international environmental treaty secretariats using a relational network approach Earth System Governance 5

Stern MJ, Briske DD, Meadow AM (2021) Opening learning spaces to create actionable knowledge for conservation Conservation Science and Practice 3

Stokes DE (1997) Pasteur's quadrant : basic science and technological innovation. Brookings Institution Press, Washington, D.C.

Sutherland WJ, Woodroof HJ (2009) The need for environmental horizon scanning. Trends Ecol Evol 24:523-527

Thomsen PF, Willerslev E (2015) Environmental DNA - An emerging tool in conservation for monitoring past and present biodiversity. Biol Conserv 183:4-18

U.S. Department of State (1956) Convention on Great Lakes Fisheries between the United States of American and Canada, TIAS 3326. In: United States treaties and other international agreements, Vol. 6, part 3, pp. 2836-2842. U.S. Government Printing Office, Washington. Available: http://www.glfc.org/pubs/conv.pdf.

Visbeck M (2008) From climate assessment to climate services. Nat Geosci 1:2-3

Vogel J, McNie E, Behar D (2016) Co-producing actionable science for water utilities. Clim Serv 2:30-40

Wall TU, Meadow AM, Horganic A (2017) Developing evaluation indicators to improve the process of coproducing usable climate science. Weather Clim Soc 9:95-107

Wamsler C (2017) Stakeholder involvement in strategic adaptation planning: Transdisciplinarity and co-production at stake? Environ Sci Policy 75:148-157

Young N (2015) Environmental sociology for the twenty first century. Oxford University Press, England

Young N, Gingras I, Nguyen VM, Cooke SJ, Hinch SG (2013) Mobilizing new science into management practice: the challenge of biotelemetry for fisheries management, a case study of Canada's Fraser River. J Int Wildlife Law Policy 16:328-348

Young N, Corriveau M, Nguyen VM, Cooke SJ, Hinch SG (2016a) How do potential knowledge users evaluate new claims about a contested resource? problems of power and politics in knowledge exchange and mobilization. J Environ Manag 184:380-388

Young N, Nguyen VM, Corriveau M, Cooke SJ, Hinch SG (2016b) Knowledge users' perspectives and advice on how to improve knowledge exchange and mobilization in the case of a co-managed fishery. Environ Sci Policy 66:170-178

Young N, Corriveau M, Nguyen VM, Cooke SJ, Hinch SG (2018) Embracing disruptive new science? biotelemetry meets co-management in Canada's Fraser river. Fisheries 43:51-60

Zielinski DP, McLaughlin RL, Pratt TC, Goodwin RA, Muir AM (2020) Single-stream recycling inspires selective fish passage solutions for the connectivity conundrum in aquatic ecosystems. Bioscience 70(10):871-886

Ziervogel G, Archer van Garderen E, Price P (2016) Strengthening the knowledge-policy interface through co-production of a climate adaptation plan: leveraging opportunities in Bergrivier Municipality South Africa. Environ Urb 28:455-474 

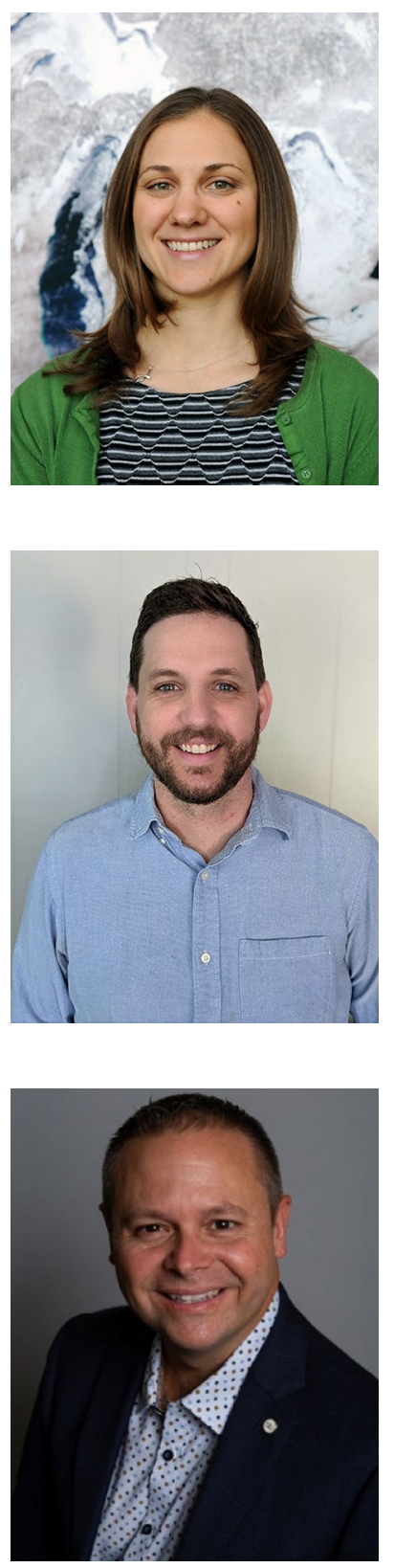

Z. Blevins is Research Impact Lead at the Great Lakes Fisheries Commission and a current $\mathrm{PhD}$ student at the University of Michigan. His work aims to enhance our understanding of the linkages between knowledge production and use, focusing specifically on strategies that individuals, research funders, and organizations can employ to enhance the utilization and impact of their knowledge creation efforts.

S. J. Cooke is a Canada Research Professor with interests in applied ecology related to aquatic ecosystems. He works closely with diverse partners to conduct research needed to solve complex environmental problems. Cooke draws upon training in the natural and social sciences to ensure that knowledge generated by his team is relevant to end-users.

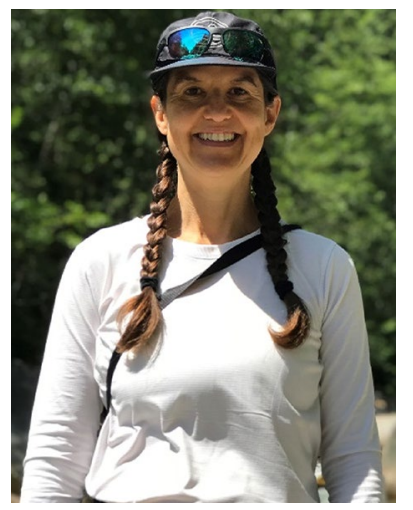

E. Dunlop is a Research Scientist in the Aquatic Research Section of the Ontario Ministry of Northern Development, Mines, Natural Resources and Forestry. Erin leads an applied research program focused on fish population dynamics in large lake ecosystems. Her research provides information needed to support management decisions and policy development with the goal of ensuring sustainability of Great Lakes' commercial and recreational fisheries.

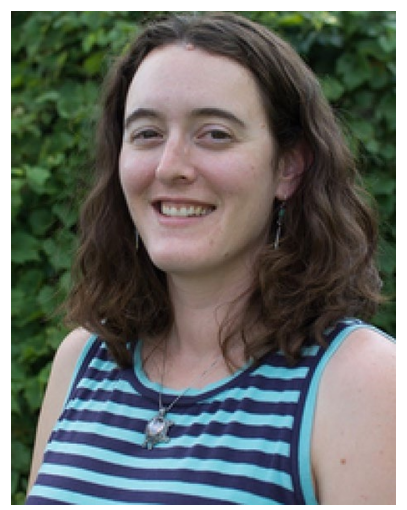

K. F. Robinson is an assistant professor in the Quantitative Fisheries Center and Department of Fisheries and Wildlife at Michigan State University. She conducts research in fisheries ecology and decision analysis for fisheries and natural resources management, particularly in the Laurentian Great Lakes.

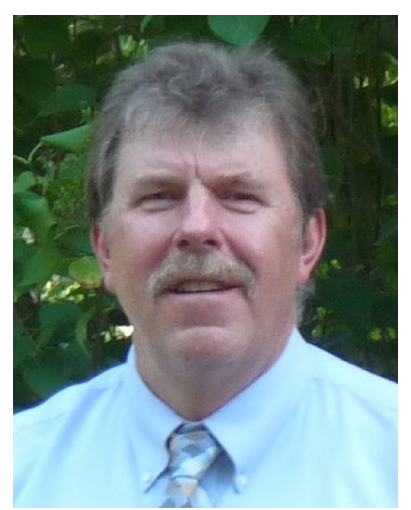

D. L. Stang is a former (retired) fisheries biologist, fisheries chief, and fish and wildlife administrator with the New York State Department of Environmental Conservation, and served as a United States Commissioner for the Great Lakes Fishery Commission.

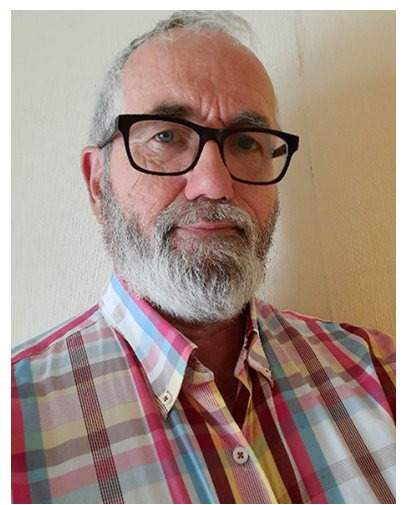

T. J. Stewart is a retired Great Lakes ecologist. He continues as a freelance ecologist specializing in aquatic food webs, modelling, science communication, and facilitation. 


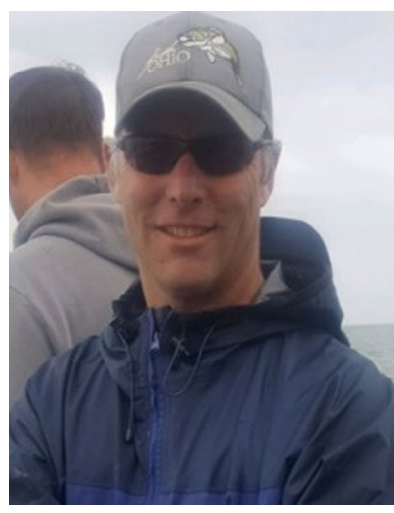

J. T. Tyson has been a Fisheries Management Program Manager at the Great Lakes Fishery Commission since 2016. In his role with the GLFC Jeff helps facilitate interjurisdictional, coordinated fisheries management with the eight states, the province of Ontario, tribes, and federal agencies with fisheries management responsibilities in the Great Lakes. In addition to helping facilitate the fisheries management process through the Great Lakes Fishery Commission, Jeff has focused on facilitating thestates, tribes, and province in identifying environmental and habitat impairments that impact fish and fisheries across the basin, working with state, tribal, provincial, and federal agencies to address these impairments.

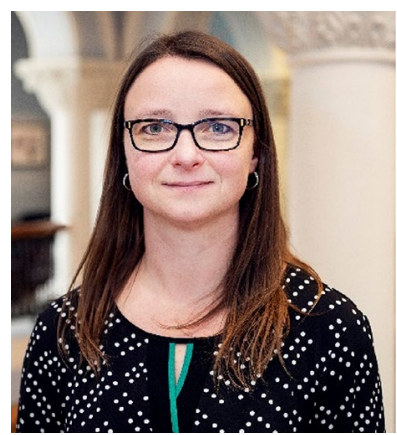

A. B. Welsh is an Associate Professor in the Wildlife and Fisheries Resources Program at West Virginia University. Her research focuses on conservation genetics, applying population genetic principles to aid in the management of fish and wildlife populations in the wild and in captivity.

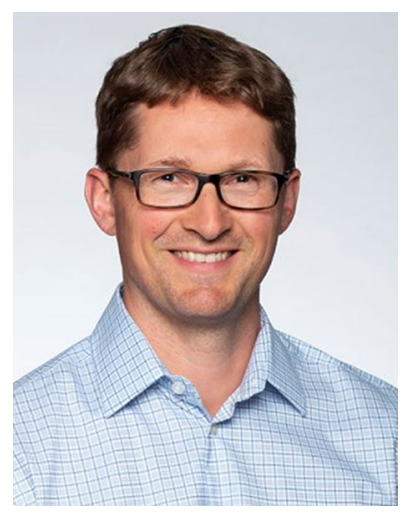

N. Young is Professor of Sociology at the University of Ottawa, Canada. His recent research includes studies of climate change politics, conflicts over fisheries and aquaculture, the role of different types of knowledge in environmental management and decision-making, and community resilience in the face of environmental changes.

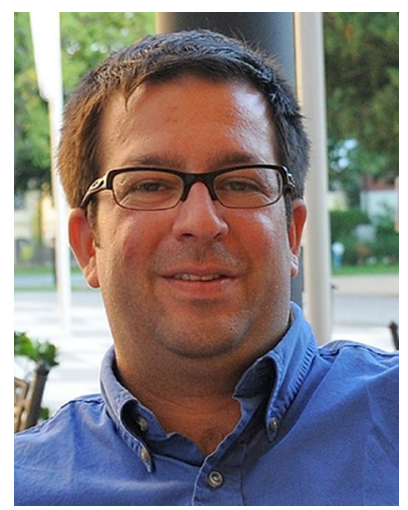

A. M. Muir is Science Director for the Great Lakes Fishery Commission. He administers fishery and sea lamprey research programs and a science transfer program throughout the Great Lakes Basin. His research is focused on the patterns and processes generating and maintaining diversity in deep-water food webs of North American large lakes, invasive species, and ecological connectivity. He strives to span knowledge systems, bridge organizations, and understand impact of Commission Science to improve program delivery. 